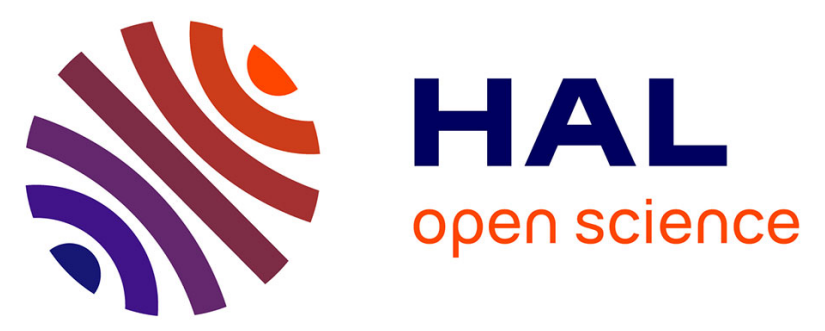

\title{
Evaluation of a Bispidine-Based Chelator for Gallium-68 and of the Porphyrin Conjugate as PET/PDT Theranostic Agent
}

Thomas Price, Steven Yap, Raphaël Gillet, Huguette Savoie, Loic Charbonniere, Ross Boyle, Aline M. Nonat, Graeme J. Stasiuk

\section{To cite this version:}

Thomas Price, Steven Yap, Raphaël Gillet, Huguette Savoie, Loic Charbonniere, et al.. Evaluation of a Bispidine-Based Chelator for Gallium-68 and of the Porphyrin Conjugate as PET/PDT Theranostic Agent. Chemistry - A European Journal, 2020, 26 (34), pp.7602-7608. 10.1002/chem.201905776 . hal-02870103

\section{HAL Id: hal-02870103 https://hal.science/hal-02870103}

Submitted on 16 Sep 2020

HAL is a multi-disciplinary open access archive for the deposit and dissemination of scientific research documents, whether they are published or not. The documents may come from teaching and research institutions in France or abroad, or from public or private research centers.
L'archive ouverte pluridisciplinaire HAL, est destinée au dépôt et à la diffusion de documents scientifiques de niveau recherche, publiés ou non, émanant des établissements d'enseignement et de recherche français ou étrangers, des laboratoires publics ou privés. 


\title{
Evaluation of a bispidine-based chelator for gallium-68 and of the porphyrin conjugate as PET/PDT theranostic agent
}

\author{
Dr Thomas W. Price, ${ }^{[a, b]} \operatorname{Dr}$ Steven Y. Yap, ${ }^{[c]} \operatorname{Dr}$ Raphaël Gillet, ${ }^{[d]}$ Huguette Savoie, ${ }^{[c]} \operatorname{Dr}$ Loïc J. \\ Charbonnière, ${ }^{[d]}$ Prof. Ross W. Boyle, ${ }^{*[c]}$ Dr Aline M. Nonat, ${ }^{*[d]}$ Dr Graeme J. Stasiuk ${ }^{*[a, b]}$
}

\begin{abstract}
In this study a bispidine ligand has been applied to the complexation of gallium(III) and radiolabelled with gallium-68 for the first time. Despite its 5-coordinate nature, the resulting complex is stable in serum for over two hours, demonstrating a ligand system well matched to the imaging window of gallium- 68 positron emission tomography (PET). To show the versatility of the bispidine ligand and its potential use in PET, the bifunctional chelator was conjugated to a porphyrin, producing a PET/PDT-theranostic, which showed the same level of stability to serum as the non-conjugated gallium-68 complex. The PET/PDT complex killed $>90 \%$ of HT-29 cells upon light irradiation at $50 \mu \mathrm{M}$. This study shows bispidines have the versatility to be used as a ligand system for gallium-68 in PET.
\end{abstract}

\section{Introduction}

Positron emission tomography (PET) is a highly sensitive imaging technique with high tissue penetration. ${ }^{[1-3]}$ This technique can allow for the in vivo imaging of diseased tissues by targeting biochemical processes; thus allowing for detection of disease before physical changes occur. Recently, gallium-68 $\left({ }^{68} \mathrm{Ga}\right)$ has found significant interest as a PET radionuclide due to its generator based production allowing for ease of access. ${ }^{[3-5]}$ Incorporation of ${ }^{68} \mathrm{Ga}$ into a radiotracer is typically achieved through the use of a chelator that complexes the PET isotope. ${ }^{[3,6,7]}$ When designing these chelators, special attention must be brought to the three following points: (i) they should form a unique radiolabeled complex, ideally in mild conditions;

[a] Dr T.W. Price, Dr G.J. Stasiuk

School of Life Sciences, Faculty of Health Sciences, University of Hull,

Cottingham Road, Hull, HU6 7RX, UK

E-mail: G.Stasiuk@hull.ac.uk

[b] Dr T.W. Price, Dr G.J. Stasiuk

Positron Emission Tomography Research Center, University of Hull,

Cottingham Road, Hull, HU6 7RX, UK

[c] Dr S.Y. Yap, H. Savoie, Prof. R.W. Boyle

Chemistry, School of Mathematical and Physical Sciences, University of Hull,

Cottingham Road, Hull, HU6 7RX, UK

E-mail: R.Boyle@hull.ac.uk

[d] Dr R. Gillet, Dr L.J. Charbonnière, Dr A.M. Nonat

Equipe de Synthèse pour l'Analyse (SynPA),

Université de Strasbourg,

CNRS, IPHC UMR 7178, F-67000 Strasbourg, France

E-mail: aline.nonat@unistra.fr

Supporting information for this article is given via a link at the end of the document. (ii) with high kinetic/thermodynamic stability; and (iii) strong resistance to hydrolysis and to transchelation reactions, occurring in particular with transferrin, and to transmetallation or competition with metals such as $\mathrm{Cu}(\mathrm{II})$ or $\mathrm{Zn}(\mathrm{II})$. Despite numerous attempts and studies, only a few ligands fulfill all the criteria. $^{[6-8]}$ These ligands are depicted in Figure 1. DOTA (1,4,7,10-tetraazacyclododecane-N,N',N",N"'-tetraacetic acid) and its conjugates (with octreotide and derivatives) are clinically in use for imaging neuroendocrine tumours ${ }^{[9]}$ although they require high temperatures and acidic conditions for radiolabeling. ${ }^{[10][11]}$ The triazacyclononane derivative (NOTA), its analogue with phosphinic pendant arms (TRAP) and the acyclic chelator $\mathrm{H}_{2}$ dedpa also need acidic conditions but no heating. ${ }^{[6,12-}$ ${ }^{14]}$ All these chelators are however subject to competition with $\mathrm{Cu}(\mathrm{II})$ and $\mathrm{Zn}(\mathrm{II}),{ }^{[15,16]}$ although TRAP displays an apparent improved selectivity for $\mathrm{Ga}(\mathrm{III}) .{ }^{[13]} \quad$ 6-amino-1,4-diazepine triacetate (DATA) chelator ${ }^{[17]}$ as well as siderophores (such as deferoxamine) ${ }^{[18]} \quad \mathrm{N}, \mathrm{N}$ '-Bis(2-hydroxybenzyl)ethylenediamine$\mathrm{N}, \mathrm{N}^{\prime}$-diacetic acid (HBED) ${ }^{[18]}$ and tris(hydroxypyridinone) $(\mathrm{THP})^{[18]}$ have the advantage to be radiolabeled in a wide $\mathrm{pH}$ range, THP being the most promising as quantitative radiochemical yields can be obtained in mild conditions. ${ }^{[19,20]}$ Several THP. bioconjugates have been studied in vivo, demonstrating either very promising tumor/body ratio $^{[21,22]}$ or disappointing results. ${ }^{[23,24]}$ These observations demonstrate that both radiocomplex and biological vector have a synergic effect on the biodistribution of the radiopharmaceutical.

For all these considerations, it is of high interest to investigate the potential of other families of ligands such as bispidines. Bispidines (chelators based on a 3,7diazabicyclo[3.3.1]nonane core) are widely used chelators with a highly preorganised coordinating site (Figure 1). ${ }^{[25,26]}$ They have been used to complex a range of metals, including radiometals such as ${ }^{64} \mathrm{Cu}$, complexes of which were found to be remarkably inert. ${ }^{[27,28]}$ Their application to $\mathrm{Ga}(\mathrm{III})$ complexation, and particularly ${ }^{68} \mathrm{Ga}$ complexation, remains relatively unexplored. ${ }^{[29]}$

The field of theranostics aims at developing agents with combined therapeutic activity and diagnostic properties in a single agent. ${ }^{[30]}$ Such theranostic agents allow for monitoring the uptake and real-time distribution of the therapeutic agent, the progression of the disease, as well as the therapeutic response. This enables an individualized treatment strategy which has been shown to be very efficient in selecting the optimal treatment, limiting adverse reactions, and implementing optimal doses as well as increasing patient adherence to treatment. ${ }^{[31-33]}$ In the case of cancer, "smart agents" with targeted drug delivery systems to the tumor are considered as a very promising alternative to conventional treatment, the effectiveness of which is limited by their absence of specificity. For these drugs, triggered by externally applied stimuli (e.g. radiation or light), monitoring their uptake and distribution is vital to optimize their 
application as it will allow for the appropriate timing of their trigger, hence maximizing their effectiveness.

Photodynamic therapy (PDT) is an example of such a therapeutic technique in which a drug is administered, and then an external trigger (in this case irradiation with a high intensity light source, such as a laser) causes the therapeutic effect. PDT agents are typically photosensitizers that are activated by absorption of visible light which first populate their excited singlet state and then, after energy transfer, their long-lived excited triplet state. This triplet state can undergo photochemical reactions in the presence of oxygen to form reactive oxygen species (ROS), including singlet oxygen. ${ }^{[34]}$ The localized production of these highly reactive species in the diseased tissues further causes the destruction of the neoplasm. Thus, PDT can allow for highly targeted toxicity with minimal off-target toxicity by only irradiating the target tissue. ${ }^{[34]}$ Tetrapyrrole structures such as porphyrins, chlorins, bacteriochlorins and phthalocyanines derivatives have been widely investigated in PDT. ${ }^{[35]}$ Porphyrins have been selected in this study due to their low toxicity, high phototoxicity, ease of synthesis, and innate tumour targeting properties. ${ }^{[34,36-40]}$

In view of the multimodal biomedical applications of metalloporphyrin, and in particular for PET/PDT purposes, ${ }^{68} \mathrm{Ga}$ has also been used previously with porphyrins. ${ }^{[41-47]}$ Work in this area started with the incorporation of ${ }^{68} \mathrm{Ga}$ into the porphyrin core directly; however this involved vigorous heating using a microwave for efficient radiolabeling. ${ }^{[41-44]}$ Furthermore, this prevents the incorporation of other metals into the porphyrin cavity, reducing the options available for optimizing the system. ${ }^{[48]}$ More recent work has therefore involved conjugating a chelator to the porphyrin and then radiolabeling the chelator. ${ }^{[45,46]}$ First experiments were performed using DOTA and NOTA. However, although they are commonly used for ${ }^{68} \mathrm{Ga}$ complexation, they were only poorly labelled when conjugated to the porphyrin. ${ }^{[45]}$ The acyclic chelator $\mathrm{H}_{3}$ Dpaa was able to be readily radiolabeled with ${ }^{68} \mathrm{Ga}$ when conjugated to a porphyrin; ${ }^{[46]}$ however, the resulting complex was insufficiently stable. ${ }^{[46,49]}$ As for bioconjugates, there is a need of finding a good chelator/porphyrin match in order to optimize both radiolabeling and PET imaging properties and PDT efficiency.

In this study we investigated the ability of a bispidine chelator to complex $\mathrm{Ga}$ (III) and to be radiolabeled with ${ }^{68} \mathrm{Ga}$ (Scheme 1). Further, we conjugated this chelator to a water soluble porphyrin and assessed the resulting conjugate's potential as a PET/PDT theranostic agent.

\section{Results and Discussion}

Complex Synthesis: The bispidine ligand, $\mathbf{L}_{1}$, was prepared as previously described. ${ }^{[28]}$ This pentadentate ligand is expected to coordinate to $\mathrm{Ga}$ (III) via the two ternary amines of the diazabicyclononane, the two nitrogen of the pyridyl groups and the acetate arm, in a similar fashion to that observed with $\mathrm{Zn}$ (II) for an analogue of L1 bearing a glycine substituent instead of the (L)-lysine [27]. Complexation of $G a(I I I)$ by $L_{1}$ was performed at $\mathrm{pH} 4.5$ at reflux. Upon complexation of $\mathrm{Ga}(\mathrm{III})$, the pyridyl protons are significantly deshielded (Figure 2), with a downfield shift of $0.3-0.8$, indicating the donation of electrons from the ring due to complexation of the cationic metal. The methyl group attached to the amine of the bispidine ring is also significantly deshielded $\left(\mathrm{CH}_{3}, \Delta \bar{\delta}_{\mathrm{H}}=0.9 \mathrm{ppm}\right)$; this suggests that the amine of the ring is involved in complexation. The proton alpha to the carboxylate of the lysine unit $\left(\mathrm{H}_{10}\right)$ is also greatly shielded; with an upfield shift of $1.2 \mathrm{ppm}$ (Figure S1).

The backbone of the cyclic structure is also locked in place, as by the coordination of the carboxylate giving an asymmetric nature evidenced by many of the resonances corresponding to protons in these environments; the resonances of $\mathrm{H}_{2}$ and $\mathrm{H}_{4}$ are distinct; these are also significantly deshielded compared to the analogous resonances in the free ligand with an upfield shift of $1.1 \mathrm{ppm}$. The proton at the apex of the ligand ring structure $\left(\mathrm{H}_{9}\right)$ is also deshielded by $0.7 \mathrm{ppm}$. Protons in the 6 and 8 positions show geminal coupling of $13.5 \mathrm{~Hz}$ and are also deshielded.

Radiochemistry: Radiolabeling of $L_{1}$ with ${ }^{68} \mathrm{Ga}$ was followed by radio-TLC. Achieving a high radiochemical yield required heating due to the rigid nature of the chelator. Furthermore, an acidic $\mathrm{pH}$ was required for effective radiolabeling; $\mathrm{pH} 4$ was found to be optimal (Figure 3a), likely due to the formation of kinetically inert $\mathrm{Ga}$ (III) hydroxides at higher $\mathrm{pHs}^{[4,50]} \mathrm{A}$ relatively high ligand concentration was also required; a radiochemical yield of $89 \%$ was achieved at a ligand concentration of $100 \mu \mathrm{M}$ whereas at $200 \mu \mathrm{M}$ a radiochemical yield of $94 \%$ was achieved (Figure 3b). These results are comparable to those previously reported for macrocyclic chelators such as DOTA, which shows a $95 \%$ RCY under similar conditions (upon heating at $85^{\circ} \mathrm{C}$ at $\mathrm{pH} 4.0$ for 30 minutes with a $100 \mu \mathrm{M}$ ligand concentration $)^{[3,51,52]}$ In terms of complexation kinetics and radiolabeling efficiency, ligand $L_{1}$ is not as efficient as NOTA $(95 \%$ RCY are obtained with no heating at $\mathrm{pH} 3.5$ for 10 minutes with a $10 \mu \mathrm{M}$ ligand concentration) and the phosphinic analogue TRAP, ${ }^{[13]}$ which can be radiolabeled at much lower concentrations $(\mathrm{c}<3 \mu \mathrm{M}, 5 \mathrm{~min}$, $\mathrm{pH}$ 3.2) at $95^{\circ} \mathrm{C}$ or even at room temperature when using a large excess of ligand. A similar trend is observed, when comparing to acyclic ligands such as THP (5 min, $\mathrm{pH} 6.5$ at $25^{\circ} \mathrm{C}$ ), $\mathrm{H}_{2}$ dedpa (5-10 min, $\mathrm{pH} 4.5$ at $25^{\circ} \mathrm{C}$ ) and $\mathrm{H}_{3}$ dpaa (99\% RCY, pH 4.5, $25^{\circ} \mathrm{C}$ at $110 \mu \mathrm{M}$ ligand concentration). These differences are not surprising when looking at the chemical structure of ligand $\mathbf{L}_{1}$, which is a pentadentate ligand and therefore not optimized for $\mathrm{Ga}$ (III) complexation in terms of kinetic, selectivity and thermodynamic stability.

However, based on previous observations with ${ }^{64} \mathrm{Cu}$ analogues, ${ }^{[53]}$ promising results in terms of kinetic inertness were expected when using a bispidine scaffold. This was indeed the case when assessed for radiochemical stability against foetal bovine serum (FBS) no decomplexation was observed over 2 hours incubation at $37^{\circ} \mathrm{C}$ (Figure S5). This is the ideal imaging window time for gallium-68's half-life, thus showing that the bispidine chelator is suitable for translation to in vivo PET applications with ${ }^{68} \mathrm{Ga}$. In addition, it is foreseen that radiochemical yields and labelling conditions may be further improved by utilizing other bispidine derivatives, in particular with hexadentate coordination mode.

Conjugation to porphyrin: To show the bispidine ligand can be utilized for applications in PET, not only as a chelator for 
gallium- 68 but as a functional tool, we conjugated the ligand to a water-soluble porphyrin to produce a PET/PDT theranostic agent. $\mathbf{L}_{\mathbf{1}}$ was coupled to a water soluble porphyrin through the terminal lysine residue. The NHS-ester of the water soluble porphyrin, $L_{2}$, was prepared as previously described ${ }^{[46,54,55]}$ and the amide bond formation was undertaken in DMF. Following semi-preparative HPLC purification, the desired bispidineporphyrin conjugate, $L_{3}$, was obtained in a $48 \%$ yield (Scheme $2)$. Conjugate formation was confirmed by mass spectrometry $\left(\mathrm{m} / \mathrm{z}=405.3[\mathrm{M}]^{3+}\right.$, Figure S11).

It is evident from the ${ }^{1} \mathrm{H}$ NMR (Figure S9) that the product contains both porphyrin and bispidine moieties; the aromatic porphyrin ${ }^{1} \mathrm{H}$ resonances, corresponding to 24 protons, are evident at $\delta_{H}=9.46,9.04$ and 8.29 for the three pyridyl units and the beta hydrogens of the porphyrin ring. The bispidine is evident through the additional aromatic resonances, corresponding to 8 protons, at 7.48 and 8.70 due to the pyridyl arms.

Conjugate complexation reaction: Complexation of $\mathrm{Ga}$ (III) was undertaken under the same conditions as for $\mathbf{L}_{1}$. Evidence for complexation was obtained from the ${ }^{1} \mathrm{H}$ NMR of the complex due to the increased shielding of the bispidine pyridyl protons (downfield shift of $0.3 \mathrm{ppm}$ ). The retention of the protons within the porphyrin ring $\left(\delta_{H}=-3.08\right)$ confirms that complexation did not take place within the porphyrin ring (Figure S12). While complexation of $\mathrm{Ga}$ (III) by porphyrins has been previously reported, ${ }^{[42]}$ this required more forcing conditions such as microwave heating and as such complexation within the porphyrin ring was not expected.

Radiolabelling of conjugate: Radiolabelling of the conjugate, $\mathbf{L}_{3}$, was achieved under the optimized conditions determined for the ligand $\mathbf{L}_{1}$. Complete complexation of the ${ }^{68} \mathrm{Ga}$ was achieved by $200 \mu \mathrm{M} \mathrm{L}_{3}$ at $\mathrm{pH} 4.5$ within 15 minutes when heated to $95^{\circ} \mathrm{C}$. This radiolabelled conjugate was assessed for its stability in FBS - all of the activity was retained within the complex over 2 hours (Figure S15). As a control, the porphyrin $\mathbf{L}_{2}$ was radiolabeled under the same conditions; radiochemical yields $<30 \%$ were achieved, showing that the conjugate $L_{3}$ has a selectivity for ${ }^{68} \mathrm{Ga}$ in the bispidine chelator, with a stability to FBS within the PET imaging window at four different timepoints $(30,60,90,120$ minutes)

Phototoxicity: To assess the viability of this system as a potential theranostic agent, the photo- and cytotoxicities of both the conjugate, $L_{3}$, and the $G a(I I I)$ complex, $\left[G a\left(L_{3}\right)\right]$, were assessed in human adenocarcinoma (HT-29) cells (Figure S16). Cells were incubated with either $\mathrm{L}_{3}$ or $\left[\mathrm{Ga}\left(\mathrm{L}_{3}\right)\right]$ at varying concentrations and irradiation was carried out using a constant dose of visible light $\left(20 \mathrm{~J} \mathrm{~cm}^{-2} ; 400-700 \mathrm{~nm}\right)$. The results were compared to a non-irradiated control. Although in a clinical setting red light is more commonly used for PDT, clinical lasers used for PDT are significantly more powerful than the quartz tungsten halogen light source used in this study. To compensate for the lower power, white light was used covering the whole porphyrin absorbance band including the strong Soret band at $422 \mathrm{~nm}$.

Under these conditions, $>90 \%$ cell death was seen at a concentration of $50 \mu \mathrm{M}$ for $\left[\mathrm{Ga}\left(\mathrm{L}_{3}\right)\right]$ when irradiated (Figure 4 ).
Minimal dark toxicity was observed at all concentrations tested. This shows phototoxicity at a similar concentration to Photofrin $\AA$, a clinically relevant porphyrin PDT agent, in HT-29 cells. ${ }^{[56]}$

\section{Conclusions}

We describe the application of a bispidine ligand, $L_{1}$, to the complexation of $\mathrm{Ga}$ (III). Furthermore, we demonstrate that this ligand can be successfully radiolabeled with ${ }^{68} \mathrm{Ga}$ producing a serum stable complex for the first time. Radiolabeling required high temperature $\left(95^{\circ} \mathrm{C}\right)$ and concentrations $(200 \mu \mathrm{M})$ to achieve near-quantitative yields (94\%). Although a higher ligand concentration than traditional chelators for gallium-68, further optimization of the denticity of the ligand and of the functional groups attached to the bispidine core may improve upon this in the future. ${ }^{[25]}$

The bifunctional bispidine, $\mathbf{L}_{1}$, was conjugated to a watersoluble porphyrin; the resulting conjugate, $\mathrm{L}_{3}$, was also applied to gallium(III) complexation and radiolabeling was achieved under the same conditions as for $\mathbf{L}_{\mathbf{1}}$. These conditions are milder than those previously reported for insertion of ${ }^{68} \mathrm{Ga}$ into the porphyrin core as microwave heating was not required Furthermore, ${ }^{1} \mathrm{H}$ NMR analysis of the Ga(III) complex confirms the presence of the protons within the porphyrin ring; this confirms that the radiolabeling is taking place at the chelator site and not at the porphyrin site. This will allow for future developments of this system to potentially incorporate alternate metals into the porphyrin ring.

$L_{3}$ and $\left[G a\left(L_{3}\right)\right]$ were shown to have low toxicity in the absence of light. Upon irradiation these systems were significantly more toxic with over $90 \%$ of $\mathrm{HT}-29$ cells being killed by $50 \mu \mathrm{M}$ of $\left[\mathrm{Ga}\left(\mathrm{L}_{3}\right)\right]$, and $79 \%$ by $\mathrm{L}_{3}$, upon irradiation.

This work demonstrates the viability of the bispidine framework for $\mathrm{Ga}$ (III) complexation and radiolabeling with ${ }^{68} \mathrm{Ga}$ for applications in PET imaging. The combination of bispidine and porphyrin produces a PDT agent that can be effectively radiolabeled with ${ }^{68} \mathrm{Ga}$ to produce a serum stable theranostic probe for PET/PDT.

\section{Experimental Section}

NMR spectra were recorded on a JEOL ECP $400 \mathrm{MHz} / \mathrm{JEOL}$ Lambda $400 \mathrm{MHz}$ spectrometer using the residual protic solvent signal as an internal reference. Chemical shifts are given in ppm ( $\delta)$ and coupling constants $(\mathrm{J})$ are given in Hertz $(\mathrm{Hz})$. Mass spectrometry data were obtained from the EPSRC National Mass Spectrometry Facility at Swansea University. UV-vis spectroscopy was carried out on a Varian Cary 50 Bio UV-vis spectrophotometer. $\mathrm{pH}$ measurements were carried out using a Jenway model 3520 $\mathrm{pH} / \mathrm{mV} /$ temperature meter with a three point calibration. All commercially available starting material used in synthesis were obtained from Sigma Aldrich, Fluorochem, and Alfa Aesar and were used without further purification. Deionised water was obtained from a Millipore Milli-Q reagent water system. All solvents were obtained from Fisher Scientific and VWR. 
HPLC analysis were performed on Agilent HPLC system. The separations were performed on a Gemini ${ }^{\circledR} 5 \mu \mathrm{m}$ C18 $110 \AA$ LC column $150 \times 4.6 \mathrm{~mm}$ (Phenomenex, $\mathrm{UK}$ ) at a flow rate of $1 \mathrm{~mL} \mathrm{~min}-1$ with a mobile phase consisting of $0.1 \%$ TFA in water (solvent $A$ ) and $0.1 \%$ TFA in acetonitrile (solvent B). Gradient [time/min](solvent A:solvent B): [0-2](95:5). [2-17](95:5-5:95).[17-19](5:95). [1921](5:95-95:5). [21-23](95:5).

Radiochemistry: The IGG100 generator was eluted with $0.6 \mathrm{M}$ aq. $\mathrm{HCl}(3 \mathrm{~mL})$. This eluate $(300-200 \mathrm{MBq})$ was diluted with $\mathrm{H}_{2} \mathrm{O}(15$ $\mathrm{mL}$ ) and passed through a Strata-X-C $33 \mu \mathrm{M}$ Cation Mixed-mode polymeric support. The activity was liberated from the column using 98:2 acetone:0.1 M aq. $\mathrm{HCl}(1 \mathrm{~mL})$. Aliquots $(\sim 30 \mathrm{MBq})$ of this solution were dried under a stream of inert gas at $90^{\circ} \mathrm{C}$ and allowed to cool before use. $100 \mu \mathrm{L}$ of ligand solution was added to the dried ${ }^{68} \mathrm{Ga}$ and shaken at the appropriate temperature. $5 \mu \mathrm{L}$ aliquots were taken for analysis by TLC. TLC analysis was performed on Kieselge $60 \mathrm{~F}_{254}$ plates (Merck) with an eluate of $0.1 \mathrm{M}$ citric acid in water. 100 $\mu \mathrm{L}$ of radiolabelling solution was added to $1.5 \mathrm{~mL}$ of foetal bovine serum and incubated at $37^{\circ} \mathrm{C}$. Aliquots were taken every 30 minutes for TLC analysis.

Cytotoxicity assays: A stock solution was made by dissolving $L_{3}$ or $\left[G a\left(L_{3}\right)\right]$ in medium $(2 \mathrm{~mL})$. The stock was sterilized by filtration through $0.22 \mu \mathrm{m}$ PES syringe filter unit (Millex-GP). The concentration of the stock was calculated by UV-vis spectroscopy using the extinction coefficient of the conjugate. The stock was diluted further with medium to give the desired concentration range. $800 \mu \mathrm{l}$ of the appropriate cells (HT-29 colon adenocarcinoma, adjusted to a concentration of $1 \times 10^{6}$ cells $/ \mathrm{ml}$ in medium with Lglutamine, was added to $200 \mu \mathrm{L}$ conjugate solution in a $12 \times 75 \mathrm{~mm}$ polystyrene FACS tube (Falcon). The cells were allowed to incubate in the dark for 1 hour at $37^{\circ} \mathrm{C}$ and $5 \% \mathrm{CO}_{2}$, after which they were centrifuged with $3 \times$ excess of medium to remove unbound $L_{3}$ or [Ga( $\left.\left.\mathrm{L}_{3}\right)\right]$. The pellet of cells was resuspended in $1 \mathrm{ml}$ medium and 4 $\mathrm{x} 100 \mu \mathrm{l}$ of each concentration was put in two 96 wells plates. One plate was irradiated with white light to a dose of $20 \mathrm{~J} \mathrm{~cm}^{-2}$ while the other serves as a dark control. After irradiation, $5 \mu \mathrm{l}$ of foetal bovine serum (FBS) was added to each well and the plates are returned to the incubator overnight. After 18 to 24 hours, the cell viability was determined using 3-[4,5-dimethylthiazol-2-yl]-2,5-diphenyltetrazolium bromide (MTT) colorimetric assay. $10 \mu \mathrm{L}$ of $12 \mathrm{mM}$ MTT solution was added to each well and incubated between 1 and 4 hours at $37{ }^{\circ} \mathrm{C}$ to allow MTT metabolisation. The crystals formed were dissolved by adding $150 \mu \mathrm{L}$ of acid-alcohol mixture $(0.04 \mathrm{M} \mathrm{HCl}$ in absolute 2-propanol). The absorbance at $570 \mathrm{~nm}$ was measured on a Biotek ELX800 Universal Microplate Reader. The results were expressed with respect to control values

Synthesis of $\left[\mathrm{Ga}\left(\mathrm{L}_{1}\right)\right]: \mathrm{L}_{1}(21 \mathrm{mg}, 33.6 \mu \mathrm{mol})$ was dissolved in water $(5 \mathrm{~mL}) . \mathrm{GaCl}_{3}(11.8 \mathrm{mg}, 67.2 \mu \mathrm{mol})$ was added and the $\mathrm{pH}$ adjusted to 4.0 with $\mathrm{NaOH}$ and $\mathrm{HCl}$. The solution was heated to reflux for 20 hours before being concentrated. The white solid was washed with acetonitrile before being dissolved in 1:1 Acetonitrile:water, filtered, and dried to give a white solid (18 mg, 90\%). ${ }^{1} \mathrm{H}$ NMR $(400 \mathrm{MHz}$, $\mathrm{D}_{2} \mathrm{O}, 298 \mathrm{~K}$ ), $\delta: 8.75\left(\mathrm{br} \mathrm{s}, 2 \mathrm{H}, \mathrm{H}_{\mathrm{a}}\right), 8.37\left(\mathrm{t}, 1 \mathrm{H}, \mathrm{H}_{\mathrm{c}},{ }^{3} \mathrm{~J}_{\mathrm{HH}}=7.8 \mathrm{~Hz}\right)$, $8.31\left(\mathrm{t}, 1 \mathrm{H}, \mathrm{H}_{\mathrm{c}},{ }^{3} \mathrm{~J}_{H H}=7.6 \mathrm{~Hz}\right), 8.02\left(\mathrm{~d}, 1 \mathrm{H}, \mathrm{H}_{\mathrm{b}} / \mathrm{H}_{\mathrm{d}},{ }^{3} \mathrm{~J}_{H H}=7.8 \mathrm{~Hz}\right)$, $7.81-7.92\left(\mathrm{~m}, 3 \mathrm{H}, \mathrm{H}_{\mathrm{b}}, \mathrm{H}_{\mathrm{d}}\right), 5.52\left(\mathrm{~s}, 1 \mathrm{H}, \mathrm{H}_{2} / \mathrm{H}_{4}\right), 5.48\left(\mathrm{~s}, 1 \mathrm{H}, \mathrm{H}_{2} / \mathrm{H}_{4}\right)$ $4.48\left(\mathrm{~s}, 1 \mathrm{H}, \mathrm{H}_{9}\right), 3.41\left(\mathrm{~d}, 1 \mathrm{H}, \mathrm{H}_{10},{ }^{3} \mathrm{~J}_{H H}=8.9 \mathrm{~Hz}\right), 3.36\left(\mathrm{~d}, 1 \mathrm{H}, \mathrm{H}_{6} / \mathrm{H}_{8}\right.$, $\left.{ }^{2} J_{H H}=13.7 \mathrm{~Hz}\right), 3.14\left(\mathrm{~d}, 1 \mathrm{H}, \mathrm{H}_{6} / \mathrm{H}_{8},{ }^{2} J_{H H}=13.3 \mathrm{~Hz}\right), 2.88(\mathrm{br} \mathrm{s}, 2 \mathrm{H}$, $\left.\mathrm{H}_{14}\right), 2.67\left(\mathrm{~d}, 1 \mathrm{H}, \mathrm{H}_{6} / \mathrm{H}_{8},{ }^{2} \mathrm{~J}_{H H}=13.5 \mathrm{~Hz}\right), 2.59\left(\mathrm{~d}, 1 \mathrm{H}, \mathrm{H}_{6} / \mathrm{H}_{8},{ }^{2} \mathrm{~J}_{H H}=\right.$ $13.5 \mathrm{~Hz}), 2.45\left(\mathrm{~s}, 3 \mathrm{H},-\mathrm{CH}_{3}\right), 1.70\left(\mathrm{br} \mathrm{s}, 1 \mathrm{H},-\mathrm{CH}_{2}-\right), 1.59$ (br s, $4 \mathrm{H}$, - $\left.\mathrm{CH}_{2}-\right), 1.29$ (br s, $\left.1 \mathrm{H},-\mathrm{CH}_{2^{-}}\right) .{ }^{13} \mathrm{C}$ NMR $\left(100 \mathrm{MHz}, \mathrm{D}_{2} \mathrm{O}, 298 \mathrm{~K}\right), \delta$ : $175.14,171.35,171.14,151.31,151.04,147.09,144.50,128.21$,
$128.03,70.58,68.69,64.29,63.79,57.81,51.55,51.26,50.79$ 46.16, 38.99, 26.68, 24.52, 22.83. MS (ESI) $\mathrm{m} / \mathrm{z}: 297.58\left[\right.$ [M] $^{2+}$

Synthesis of $L_{3}: L_{2}(50 \mathrm{mg}, 42 \mu \mathrm{mol})$ and $L_{1}(50 \mathrm{mg}, 80 \mu \mathrm{mol})$ were taken up in dry DMF $(5 \mathrm{~mL})$ and $\mathrm{Et}_{3} \mathrm{~N}(50 \mu \mathrm{L}, 360 \mu \mathrm{mol})$ was added. The reaction was allowed to proceed at room temperature overnight protected from light. Solvent was removed under reduced pressure and the reaction was purified using semi-preparative HPLC. The solvent was concentrated under reduced pressure, washed with diethyl ether, and dried under vacuum. The residue was precipitated by addition of diethyl ether over a methanol solution to yield a purple solid (27 mg, $20 \mu \mathrm{mol}, 48 \%)$. ${ }^{1} \mathrm{H}$ NMR $\left(400 \mathrm{MHz}\right.$, DMSO- $\left.d_{6}\right) \delta: 9.46$ (s, $6 \mathrm{H}$, porphyrin-m-Py), 9.16-8.92 $(\mathrm{m}, 14 \mathrm{H}, \beta \mathrm{H}$, porphyrin-o-Py) 8.81-52 (m, 2H, bispidine-Py), $8.29(\mathrm{~d}, \mathrm{~J}=16.4 \mathrm{~Hz}, 4 \mathrm{H}$, porphyrino,m-Ph), 7.00-7.08 (m, 6H, bispidine-Py), 5.02 (br s, 2H), 4.69 (s, 9H, $\left.\mathrm{N}-\mathrm{CH}_{3}\right), 3.95(2,1 \mathrm{H}), 3.60-3.43(\mathrm{~m}, 4 \mathrm{H}), 3.20-2.94(\mathrm{~m}, 4 \mathrm{H}), 2.28-$ $1.51(\mathrm{~m}, 8 \mathrm{H}),-3.06(\mathrm{~s}, 2 \mathrm{H}, \mathrm{NH}) .{ }^{13} \mathrm{C}$ NMR $\left(100 \mathrm{MHz}, \mathrm{DMSO}-D_{6}\right) \delta$ : $204.09,198.95,198.73,172.05,166.35,158.37,158.06,156.99$ 149.46, 148.08, $144.76(\beta C), 137.45,135.04,132.66(\beta C), 127.03$, $126.58,126.22,123.33,123.19,122.42,119.43,118.86,116.43$, $115.26,75.01,74.27,67.65,62.26,61.38,58.60,50.57,48.29$, 44.07, 43.32, 42.06, 29.27, 19.70. MS (ESI) m/z: 405.3 [M] ${ }^{3+}$, HRMS (ESI) $\mathrm{m} / \mathrm{z}: 405.1727$ (calculated for $\mathrm{C}_{71} \mathrm{H}_{67} \mathrm{~N}_{12} \mathrm{O}_{8}$ 405.1729). UV-Vis $\left(\mathrm{H}_{2} \mathrm{O}\right), n m: 422,519,558,582,639 . \varepsilon(422 \mathrm{~nm})=258300 \mathrm{M}^{-1} \mathrm{~cm}^{-1}$.

Synthesis of $\left[\mathrm{Ga}\left(\mathrm{L}_{3}\right)\right]: \mathrm{L}_{3}(1 \mathrm{mg}, 0.76 \mu \mathrm{mol})$ was dissolved in water $(0.4 \mathrm{~mL})$. To this solution was added acetate buffer $(\mathrm{pH} 4.5,1 \mathrm{M}, 50$ $\mu \mathrm{L})$ and a solution of $\mathrm{GaCl}_{3}(70 \mu \mathrm{L}, 57 \mathrm{mM}, 4.0 \mu \mathrm{mol})$. The reaction was allowed to proceed overnight at $100{ }^{\circ} \mathrm{C}$. Concentration of the reaction solution, followed by purification by semi-preparative HPLC, yielded the product as a purple solid. ${ }^{1} \mathrm{H}$ NMR $\left(400 \mathrm{MHz}\right.$, DMSO- $\left.d_{6}\right)$ $\delta 9.49(\mathrm{~s}, 6 \mathrm{H}$, porphyrin-m-Py), 9.23-8.67 (m, 16H, bispidine- $\mathrm{Py}, \beta \mathrm{H}$ porphyrin-o-Py), $8.62(\mathrm{~s}, 1 \mathrm{H}$, bispidine-Py), 8.42-8.11 (m, 6H, bispidine-Py, porphyrin-o,m-Ph), 7.94-7.64 (m, 3H, bispidine-Py), 5.48-4.99 (m, 2H), $4.69\left(\mathrm{~s}, 9 \mathrm{H}, \mathrm{N}-\mathrm{CH}_{3}\right), 4.04(\mathrm{~s}, 1 \mathrm{H}), 3.10-2.52(\mathrm{~m}$, $4 \mathrm{H}), 2.36-0.70(\mathrm{~m}, 12 \mathrm{H}),-3.08(\mathrm{~s}, 2 \mathrm{H}, \mathrm{NH}) . \mathrm{MS}(\mathrm{ESI}), \mathrm{m} / \mathrm{z}: 433.8$ [M$\left.3 \mathrm{Cl}+\mathrm{H}_{2} \mathrm{O}\right]^{3+}$, HRMS (ESI), m/z: 433.8077 (calculated. for $\mathrm{C}_{71} \mathrm{H}_{66} \mathrm{GaN}_{12} \mathrm{O}_{9}$ 433.8107). UV-Vis $\left(\mathrm{H}_{2} \mathrm{O}\right) \mathrm{nm}: 422,519,556,585$, 640. $\varepsilon(422 \mathrm{~nm})=240000 \mathrm{M}^{-1} \mathrm{~cm}^{-1}$.

Keywords: Gallium-68・ Bispidine $•$ PET • PDT • theranostic

[1] M. E. Phelps, Proc. Natl. Acad. Sci. U. S. A. 2000, 97, 9226-9233

[2] P. W. Miller, N. J. Long, R. Vilar, A. D. Gee, Angew. Chemie - Int Ed. 2008, 47, 8998-9033.

[3] T. W. Price, J. Greenman, G. J. Stasiuk, Dalton Trans. 2016, 45, 15702-15724.

[4] M. D. Bartholomä, A. S. Louie, J. F. Valliant, J. Zubieta, Chem. Rev. 2010, 110, 2903-2920.

[5] S. R. Banerjee, M. G. Pomper, Appl. Radiat. Isot. 2013, 76, 2-13.

[6] E. W. Price, C. Orvig, Chem. Soc. Rev. 2014, 43, 260-290.

[7] B. P. Burke, G. S. Clemente, S. J. Archibald, J. Labelled Comp. Radiopharm. 2014, 57, 239-243.

[8] T. W. Price, J. Greenman, G. J. Stasiuk, Dalton Trans. 2016, 45, 15702-15724.

[9] M. S. Hofman, G. Kong, O. C. Neels, P. Eu, E. Hong, R. J. Hicks, J. Med. Imaging Radiat. Oncol. 2012, 56, 40-47.

[10] M. Ocak, M. Antretter, R. Knopp, F. Kunkel, M. Petrik, N. Bergisadi, C. Decristoforo, Appl. Radiat. Isot. 2010, 68, 297-302. 
[11] M. Petrik, P. A. Knetsch, R. Knopp, G. Imperato, M. Ocak, E. Von Guggenberg, R. Haubner, R. Silbernagl, C. Decristoforo, Nucl. Med. Commun. 2011, 32, 887-895.

[12] E. Boros, C. L. Ferreira, J. F. Cawthray, E. W. Price, B. O. Patrick, D. W. Wester, M. J. Adam, C. Orvig, J. Am. Chem. Soc. 2010, 132, 15726-15733.

[13] J. Šimeček, M. Schulz, J. Notni, J. Plutnar, V. Kubíček, J. Havlíčková, P. Hermann, Inorg. Chem. 2012, 51, 577-590.

[14] J. Notni, J. Simecek, P. Hermann, H. J. Wester, Chem. Eur. J. 2011, 17, 14718-14722.

[15] J. Simecek, P. Hermann, H. J. Wester, J. Notni, ChemMedChem 2013, 8, 95-103.

[16] E. Farkas, J. Nagel, B. P. Waldron, D. Parker, I. Tóth, E. Brücher, F. Rösch, Z. Baranyai, Chem. - A Eur. J. 2017, 23, 10358-10371.

[17] J. Seemann, B. P. Waldron, F. Roesch, D. Parker, ChemMedChem 2015, 10, 1019-1026.

[18] M. I. Tsionou, C. E. Knapp, C. A. Foley, C. R. Munteanu, A. Cakebread, C. Imberti, T. R. Eykyn, J. D. Young, B. M. Paterson, P. J. Blower, et al., RSC Adv. 2017, 7, 49586-49599.

[19] C. Imberti, Y. L. Chen, C. A. Foley, M. T. Ma, B. M. Paterson, Y. Wang, J. D. Young, R. C. Hider, P. J. Blower, Dalton Trans. 2019, 48, 4299-4313.

[20] D. J. Berry, Y. M. Ma, J. R. Ballinger, R. Tavare, A. Koers, K. Sunassee, T. Zhou, S. Nawaz, G. E. D. Mullen, R. C. Hider, et al., Chem. Commun. 2011, 47, 7068-7070.

M. S. Hofman, P. Eu, P. Jackson, E. Hong, D. Binns, A. Iravani, D. Murphy, C. Mitchell, S. Siva, R. J. Hicks, et al., J. Nucl. Med. 2017 59, 625-631.

[22] T. Derlin, S. Schmuck, C. Juhl, S. Teichert, J. Zörgiebel, H. J. Wester, S. M. Schneefeld, A. C. A. Walte, J. T. Thackeray, T. L. Ross, et al., Mol. Imaging Biol. 2018, 20, 650-658.

[23] M. T. Ma, C. Cullinane, C. Imberti, J. Baguña Torres, S. Y. A. A. Terry, P. Roselt, R. J. Hicks, P. J. Blower, J. Baguna Torres, S. Y. A. A. Terry, et al., Bioconjug. Chem. 2016, 27, 309-318.

D. Lobeek, G. M. Franssen, M. T. Ma, H. J. Wester, C. Decristoforo, W. J. G. Oyen, O. C. Boerman, S. Y. A. Terry, M. Rijpkema, J. Nucl. Med. 2018, 59, 1296-1301.

[25] P. Comba, M. Kerscher, K. Rück, M. Starke, Dalton Trans. 2018, 15983-15993.

[26] A. Nonat, A. Roux, M. Sy, L. Charbonnière, Dalton Trans. 2019, 48, DOI 10.1039/C9DT03480C.

[27] A. Roux, A. M. Nonat, J. Brandel, V. Hubscher-Bruder, L. J. Charbonnière, Inorg. Chem. 2015, 54, 4431-4444.

[28] A. Roux, R. Gillet, S. Huclier-Markai, L. Ehret-Sabatier, L. J. Charbonnière, A. M. Nonat, Org. Biomol. Chem. 2017, 15, 14751483.

[29] P. Comba, L. Grimm, C. Orvig, K. Rück, H. Wadepohl, Inorg. Chem. 2016, 55, 12531-12543.

[30] S. S. Kelkar, T. M. Reineke, Bioconjug. Chem. 2011, 22, 1879-1903.

[31] U. Garske, M. Sandström, S. Johansson, D. Granberg, H. Lundqvist, M. Lubber-ink, A. Sundin, B. Eriksson, Theranostics 2012, 2, 459471
S. K. Pushpan, S. Venkatraman, V. G. Anand, J. Sankar, D. Parmeswaran, S. Ganesan, T. K. Chandrasheka, Curr. Med. Chem. - Anti-Cancer Agents 2002, 2, 187-207.

[39] L. B. Josefsen, R. W. Boyle, Theranostics 2012, 2, 916-966.

[40] I. J. Macdonald, T. J. Dougherty, J. Porphyr. Phthalocyanines 2001, 5, 105-129.

[41] M. Bhadwal, T. Das, H. Dev Sarma, S. Banerjee, Mol. Imaging Biol. 2015, 17, 111-118

[42] F. Bryden, H. Savoie, E. V Rosca, R. W. Boyle, Dalton Trans. 2015, 44, 4925-4932.

[43] Y. Fazaeli, A. R. Jalilian, M. M. Amini, K. Ardaneh, A. Rahiminejad, F. Bolourinovin, S. Moradkhani, A. Majdabadi, Nucl. Med. Mol. Imaging 2012, 46, 20-26.

[44] F. Zoller, P. J. Riss, F.-P. Montforts, D. K. Kelleher, E. Eppard, F. Rösch, Nucl. Med. Biol. 2013, 40, 280-288.

[45] M. Guleria, T. Das, J. Amirdhanayagam, H. D. Sarma, A. Dash, Cancer Biother. Radiopharm. 2018, 33, 1-9.

[46] S. Y. Yap, T. W. Price, H. Savoie, R. W. Boyle, G. J. Stasiuk, Chem Commun. 2018, 54, 7952-7954

[47] Y. Fazaeli, M. A. Hosseini, F. Shahabinia, S. Feizi, J. Radioanal. Nucl. Chem. 2019, 320, 201-207.

[48] M. Imran, M. Ramzan, A. K. Qureshi, M. Azhar Khan, M. Tariq, Biosensors 2018, 8, 1-17.

[49] T. W. Price, J. Gallo, V. Kubíček, Z. Böhmová, T. J. Prior, J. Greenman, P. Hermann, G. J. Stasiuk, Dalton Trans. 2017, 46, 16973-16982.

[50] M. Fani, J. P. André, H. R. Maecke, J. P. Andre, H. R. Maecke, Contrast Media Mol. Imaging 2008, 3, 53-60.

[51] L. Wei, Y. Miao, F. Gallazzi, T. P. Quinn, M. J. Welch, A. L. Vavere, J. S. Lewis, Nucl. Med. Biol. 2007, 34, 945-953.

[52] G. Kramer-Marek, N. Shenoy, J. Seidel, G. L. Griffiths, P. Choyke, J. Capala, Eur. J. Nucl. Med. Mol. Imaging 2011, 38, 1967-1976.

[53] R. Gillet, A. Roux, J. Brandel, S. Huclier-Markai, F. Camerel, O. Jeannin, A. M. Nonat, L. J. Charbonnière, Inorg. Chem. 2017, 56, 11738-11752.

[54] C. Spagnul, L. C. Turner, F. Giuntini, J. Greenman, R. W. Boyle, J. Mater. Chem. B 2017, 5, 1834-1845.

[55] A. D. Adler, F. R. Longo, J. D. Finarelli, J. Goldmacher, J. Assour, L. Korsakoff, J. Org. Chem. 1967, 32, 476.

[56] A. Hajri, S. Wack, C. Meyer, M. K. Smith, C. Leberquier, M. Kedinger, M. Aprahamian, Photochem. Photobiol. 2004, 75, 140. 


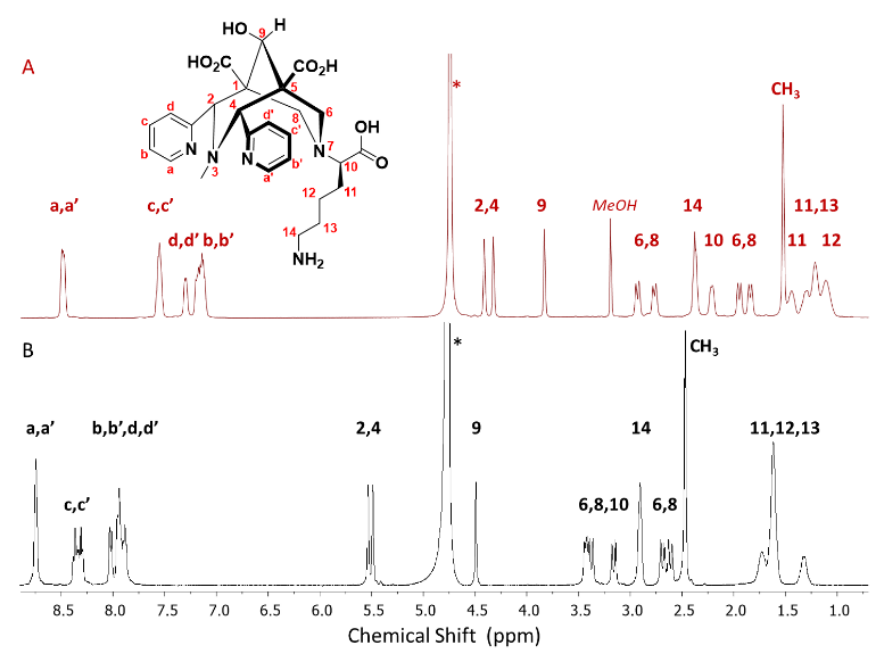

Figure 2. ${ }^{1} \mathrm{H} N \mathrm{NMR}(400 \mathrm{MHz}, 298 \mathrm{~K})$ of $\left.A\right) \mathrm{L}_{1}\left(d_{4}-\mathrm{MeOH}\right)$ and $\left.\mathrm{B}\right)\left[\mathrm{Ga}\left(\mathrm{L}_{1}\right)\right]\left(\mathrm{D}_{2} \mathrm{O}\right)$.Figure Caption. 


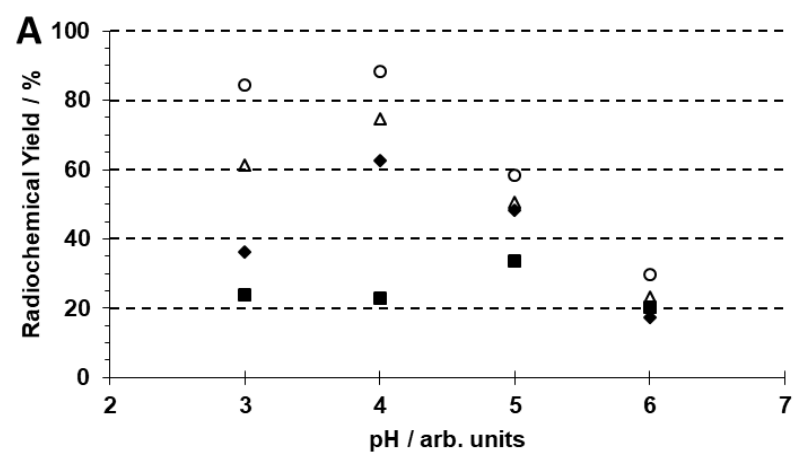

-25 oC $\bullet 45$ oC $\triangle 65$ oC $\circ 85$ oC

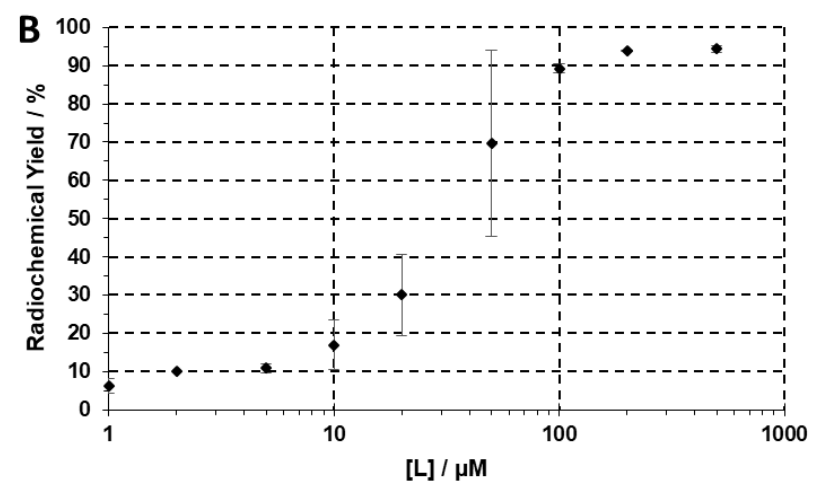

Figure 3. Radiolabelling of $\mathrm{L}_{1}$ with ${ }^{68} \mathrm{Ga}$. A) Effect of $\mathrm{pH}$ and temperature on radiolabelling. $\left[L_{1}\right]=100 \mu \mathrm{M}, t=15 \mathrm{minutes}, I=0.1 \mathrm{M} \mathrm{NH}{ }_{4} \mathrm{OAc}$. B) Effect of concentration on radiolabelling. $p H=4, T=95^{\circ} \mathrm{C}, t=15$ minutes, $I=0.1 \mathrm{M} \mathrm{NH}_{4} \mathrm{OAc}$. 

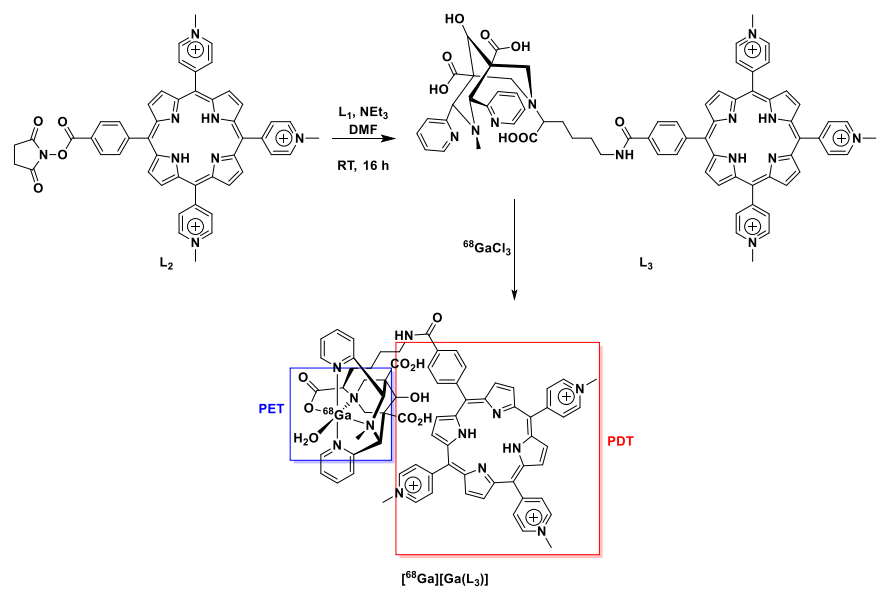

Scheme 2. Synthesis and radiolabelling of $L_{3}$ to produce a PET/PDT theranostic agent. 


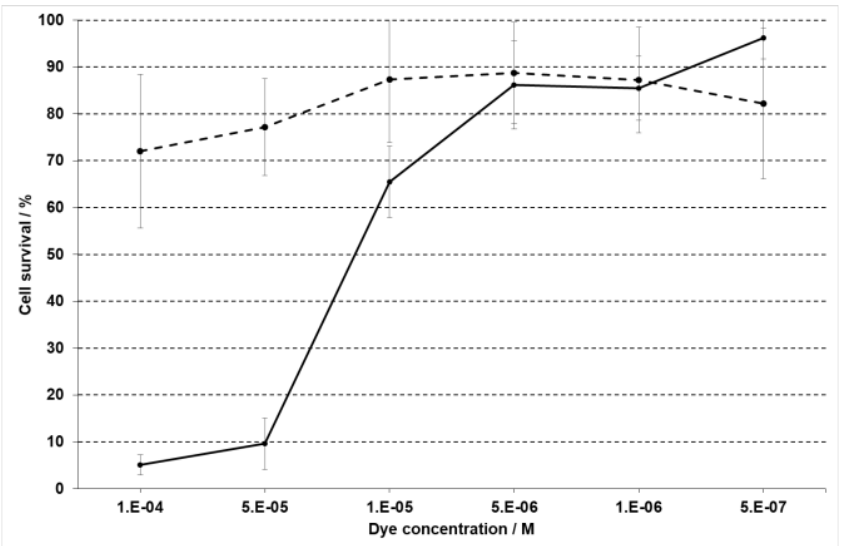

Figure 4. Toxicity of $\left[\mathrm{Ga}\left(\mathrm{L}_{3}\right)\right]$ in $\mathrm{HT}-29$ cells as measured by MTT assay. Solid line indicates irradiated toxicity, dashed line indicates non-irradiated toxicity. 


\section{Electronic Supplementary Material}
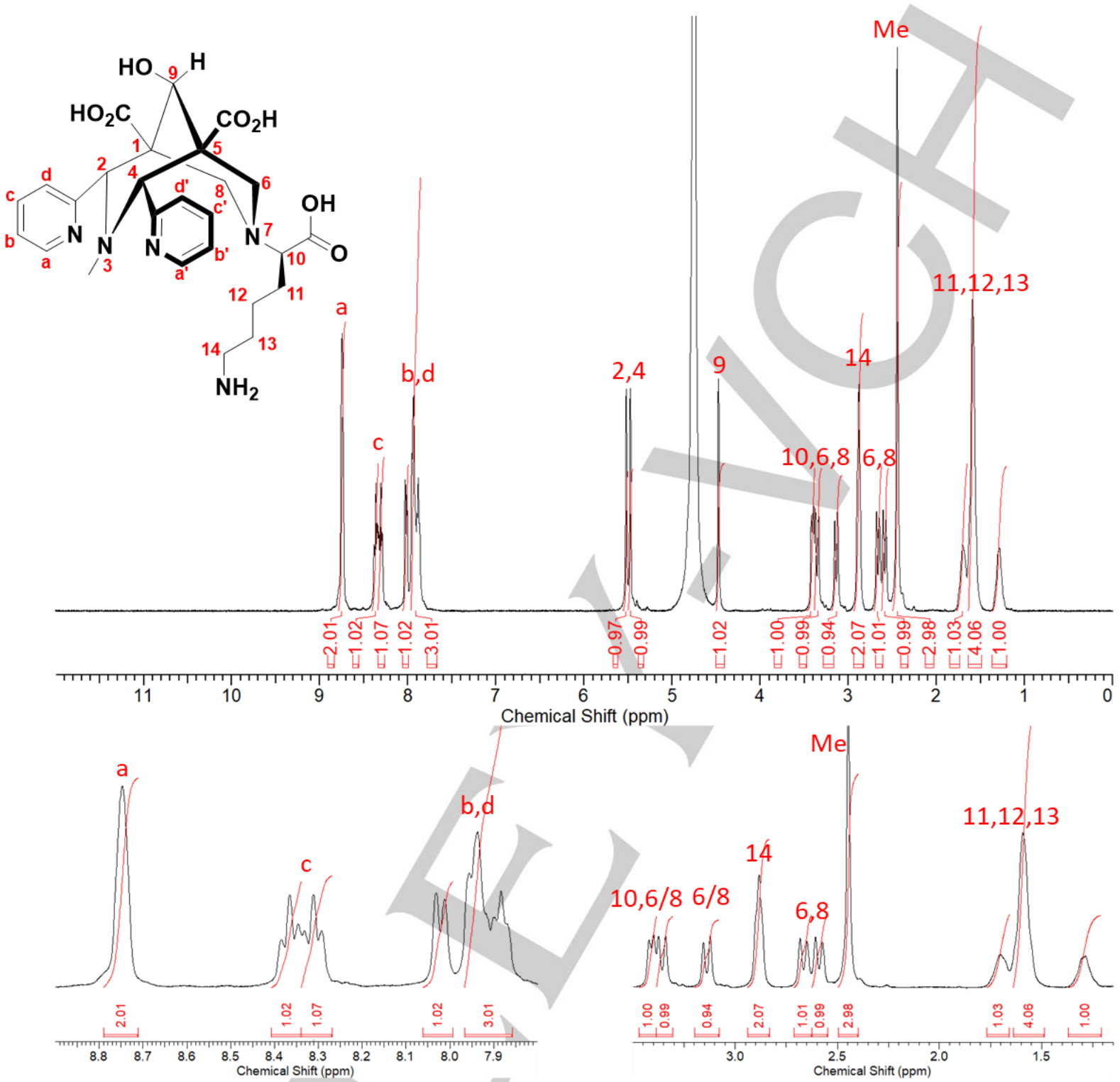

Figure S1. ${ }^{1} \mathrm{H}$ NMR of $\left[\mathrm{Ga}\left(\mathrm{L}_{1}\right)\right]\left(400 \mathrm{MHz}, \mathrm{D}_{2} \mathrm{O}, 298 \mathrm{~K}\right)$. Inset: annotated structure of $\mathrm{L}_{1}$ and expanded regions of ${ }^{1} \mathrm{H}$ NMR. 


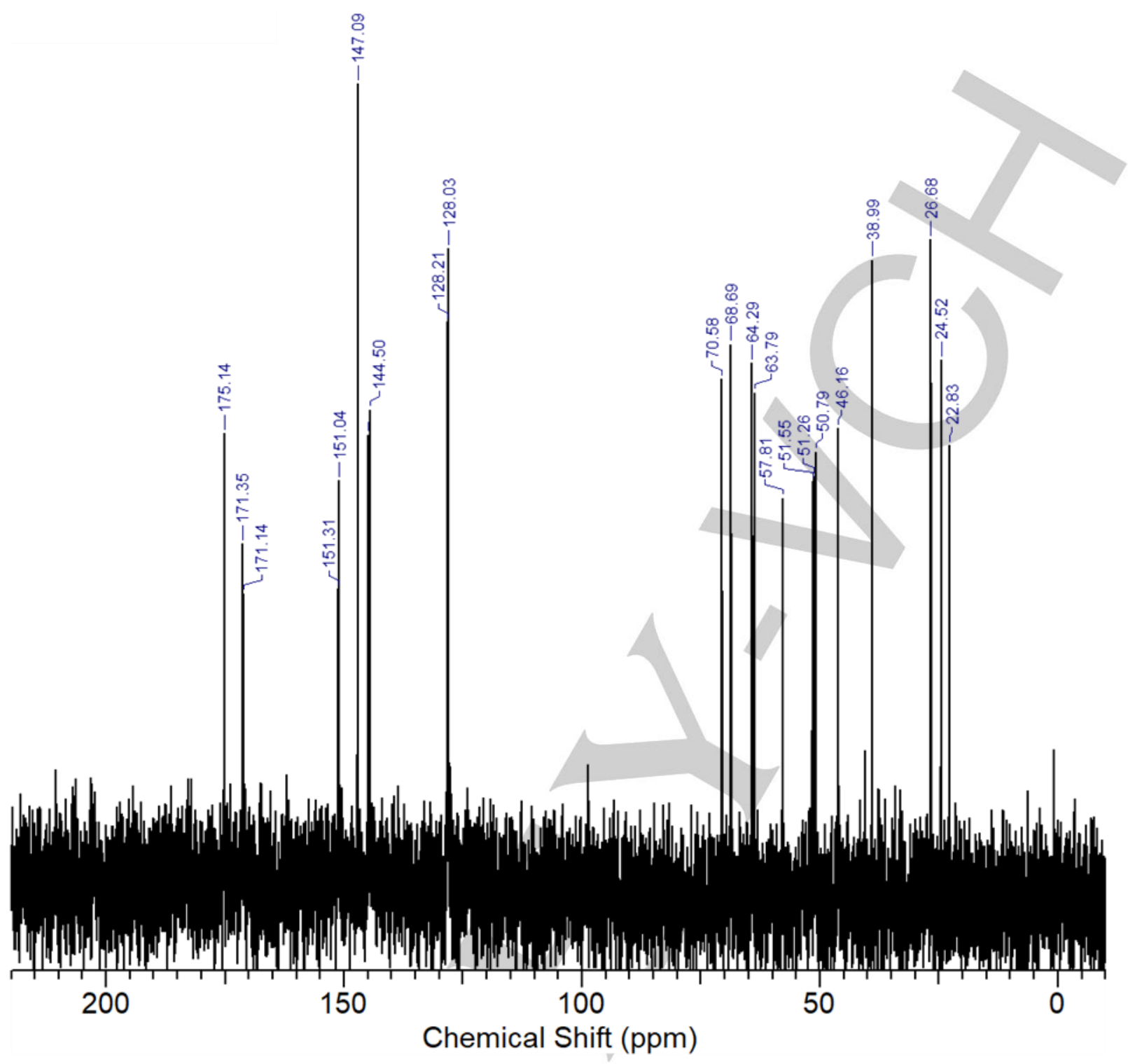

Figure S2. ${ }^{13} \mathrm{C}$ NMR of $\left[\mathrm{Ga}\left(\mathrm{L}_{1}\right)\right]\left(100 \mathrm{MHz}, \mathrm{D}_{2} \mathrm{O}, 298 \mathrm{~K}\right)$. 


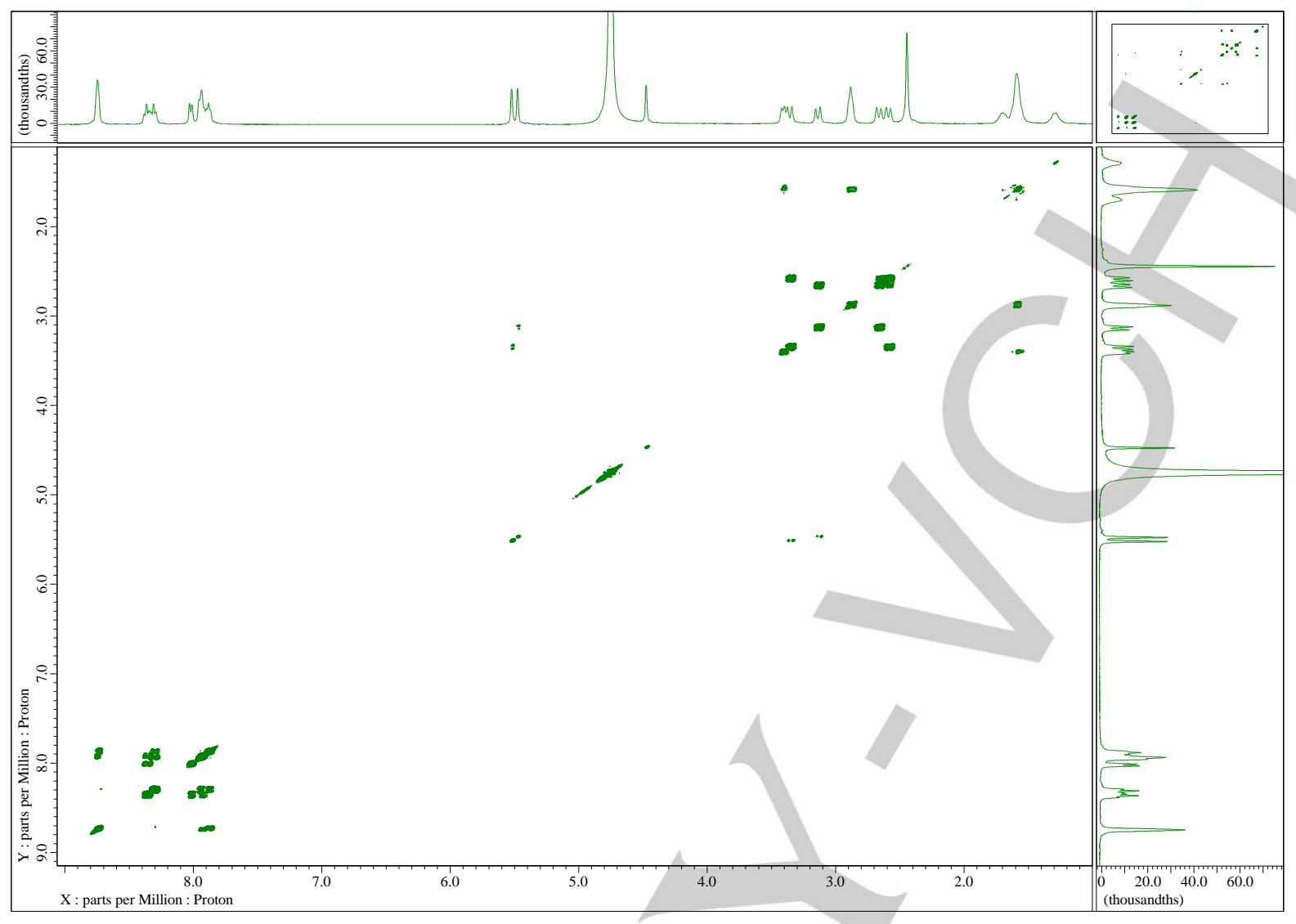

Figure $3 \cos Y$ of $\left[\mathrm{Ga}\left(\mathrm{L}_{1}\right)\right]$. 


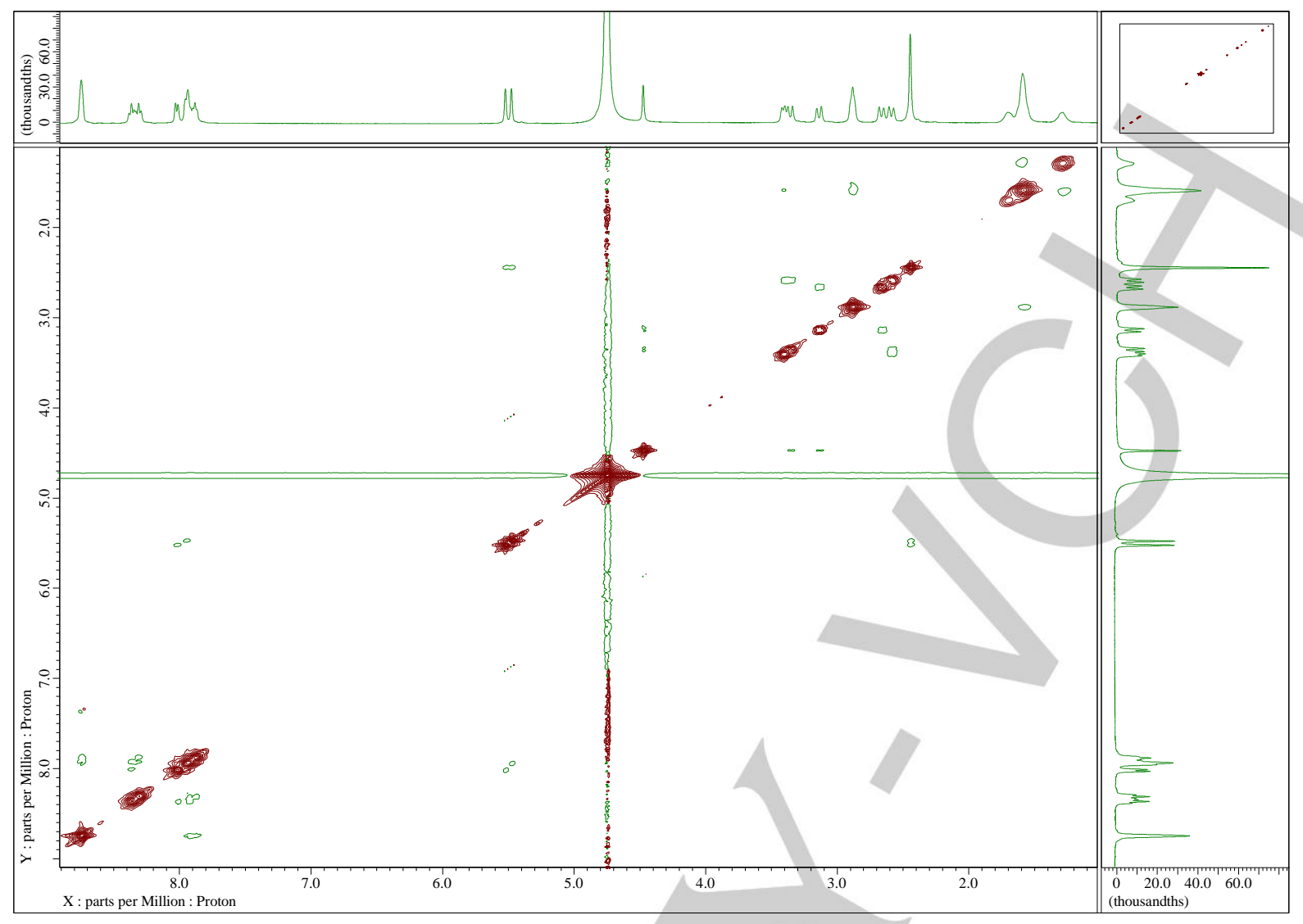

Figure S4. NOESY of [Ga(L1)]. 


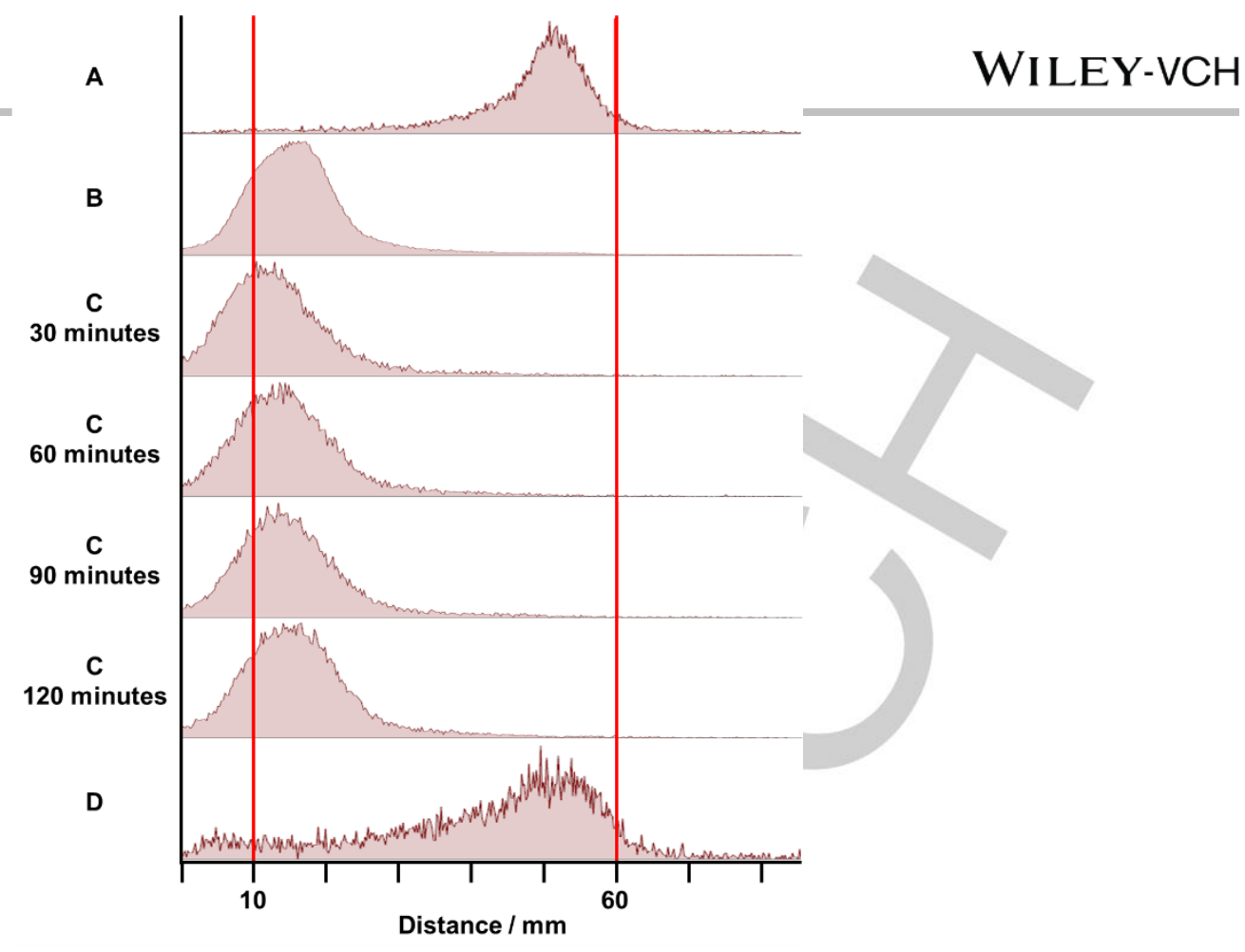

Figure S5. Radio-TLC of radiolabelling reaction of $\mathbf{L}_{1}$ with $\left[{ }^{68} \mathrm{Ga}\right]\left[\mathrm{GaCl}_{3}\right]$. A) $\left[{ }^{68} \mathrm{Ga}\right]\left[\mathrm{GaCl}_{3}\right]$ in aqueous solution. B) Radiolabelling mixture of $\mathbf{L}_{1}(200 \mu \mathrm{M})$ and $\left[{ }^{68} \mathrm{Ga}_{[}\left[\mathrm{GaCl}_{3}\right]\right.$ following incubation at $95^{\circ} \mathrm{C}$, for 15 minutes, $\mathrm{pH}$ 4. C) Incubation of an aliquot of $\mathrm{B}$ with $\mathrm{FBS}$ at $37^{\circ} \mathrm{C}$ for indicated time period. D) $\left.\left[{ }^{68} \mathrm{Ga}\right][\mathrm{GaCl}]_{3}\right]$ incubated with FBS. 

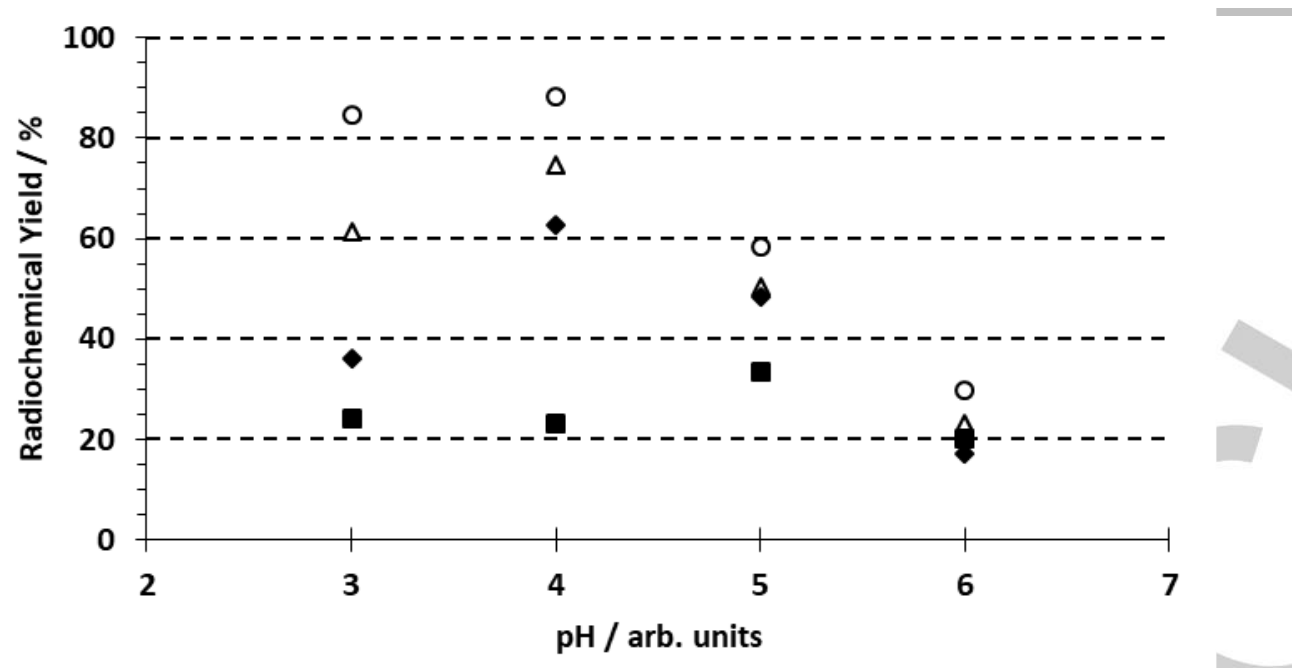

- 25 oC $\bullet 45$ oC $\Delta 65$ oC 085 oC

Figure S6. Effect of $\mathrm{pH}$ on radiolabelling of $\mathbf{L}_{1}$ with ${ }^{68} \mathrm{Ga}$ at various temperatures. $\left[L_{1}\right]=100 \mu \mathrm{M}, t=15$ minutes, $I=0.1 \mathrm{M} \mathrm{NH}_{4} \mathrm{OAc}$. 


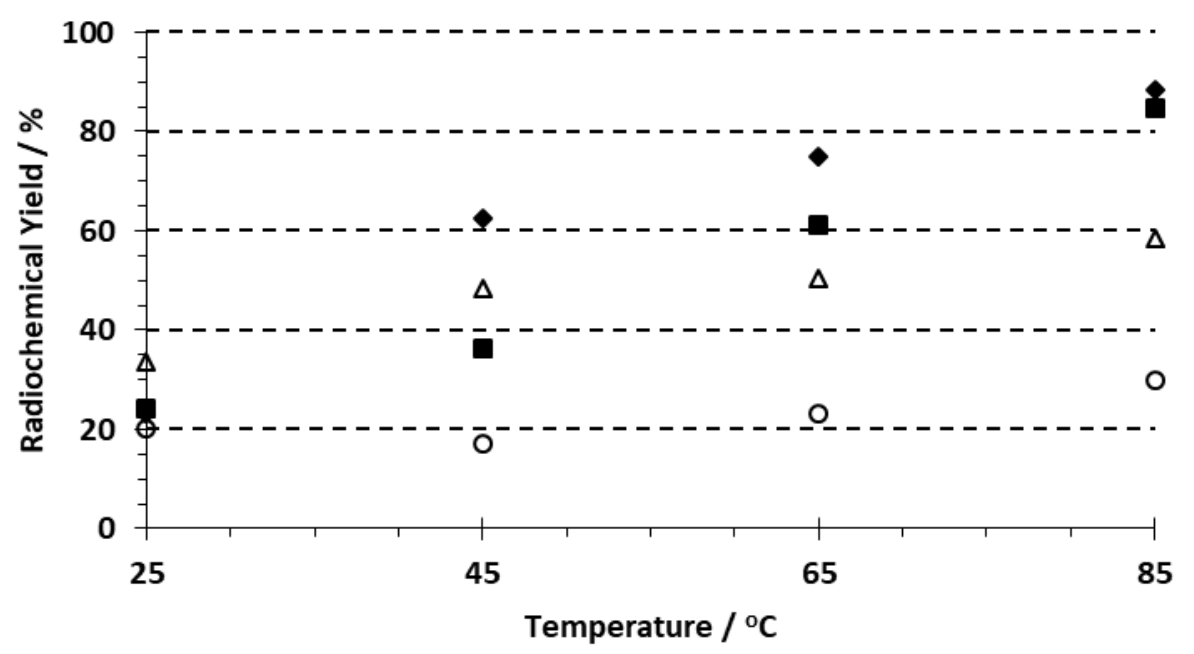

$\square \mathrm{pH} 3 \bullet \mathrm{pH} 4 \Delta \mathrm{pH} 5 \quad \mathrm{pH} 6$

Figure S7. Effect of temperature on radiolabelling of $L_{1}$ with ${ }^{68}$ Ga at various $p H$ values. $\left[L_{1}\right]=100 \mu \mathrm{M}, t=15$ minutes, $I=0.1 \mathrm{M} \mathrm{NH}_{4} \mathrm{OAc}$. 


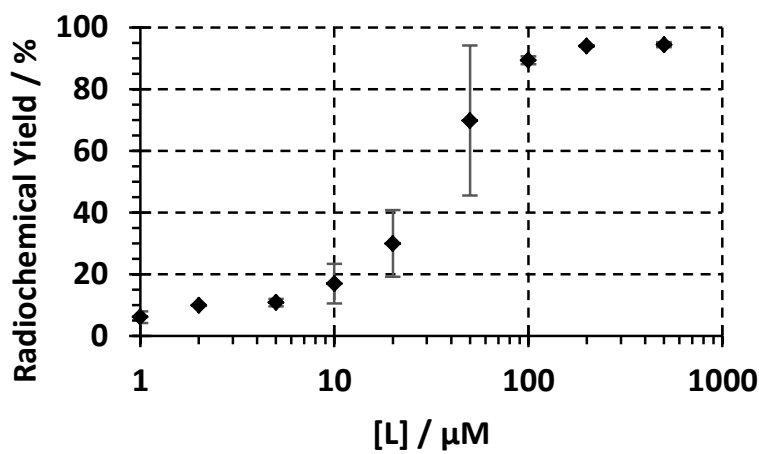

Figure S8. Effect of concentration on radiolabelling of $L_{1}$ with ${ }^{68} \mathrm{Ga} p H=4, T=95{ }^{\circ} \mathrm{C}, t=15$ minutes, $I=0.1 \mathrm{M} \mathrm{NH}_{4} \mathrm{OAc}$. 


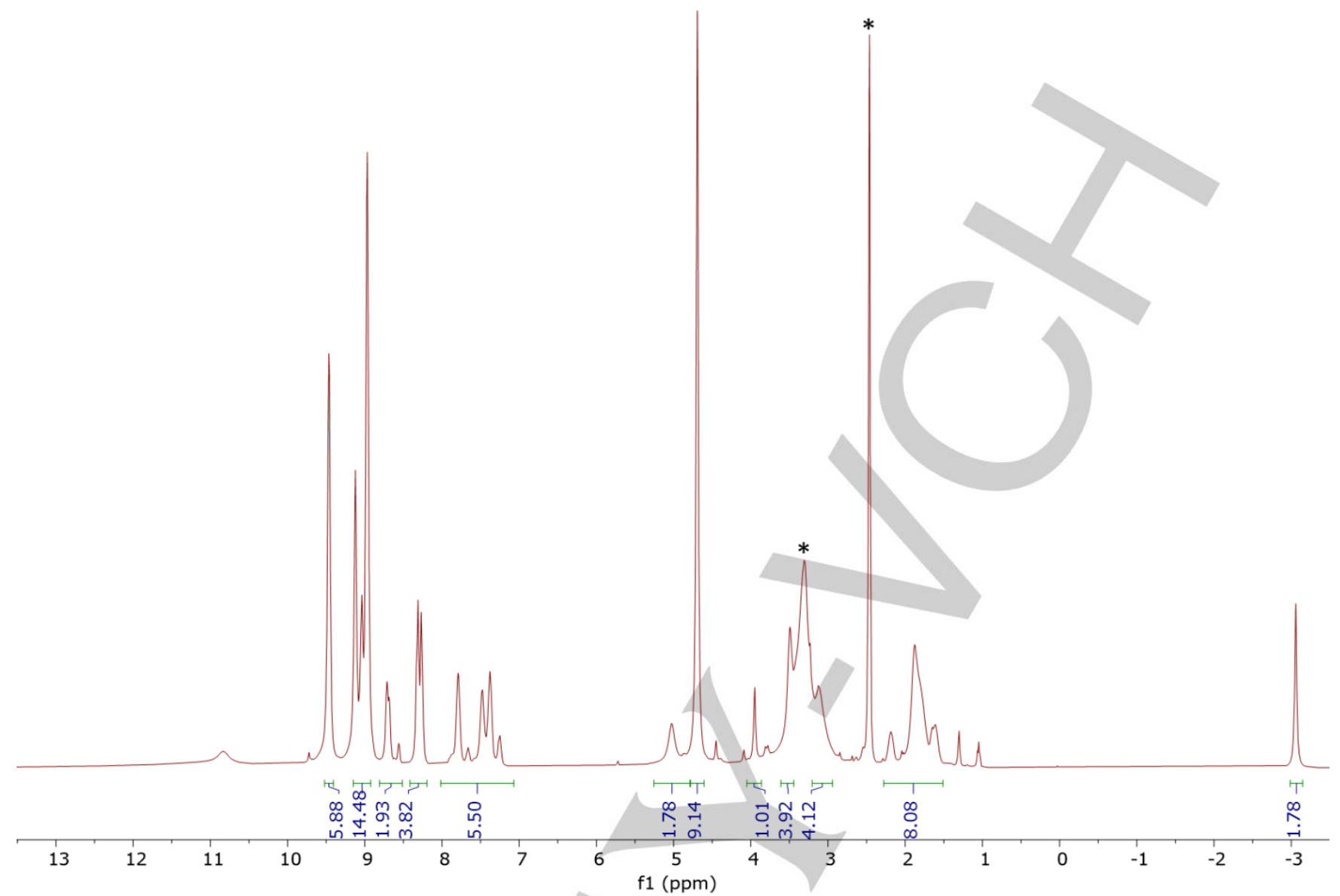

Figure S9. ${ }^{1} \mathrm{H}$ NMR of $\mathrm{L}_{3}\left(d_{6}\right.$-DMSO, $\left.400 \mathrm{MHz}, 298 \mathrm{~K}\right) .{ }^{*}$ indicates residual solvent signal. 


$$
\text { 量路 }
$$

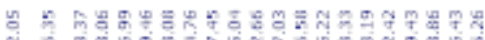

20

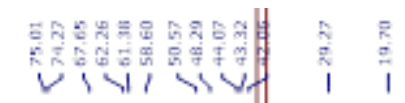
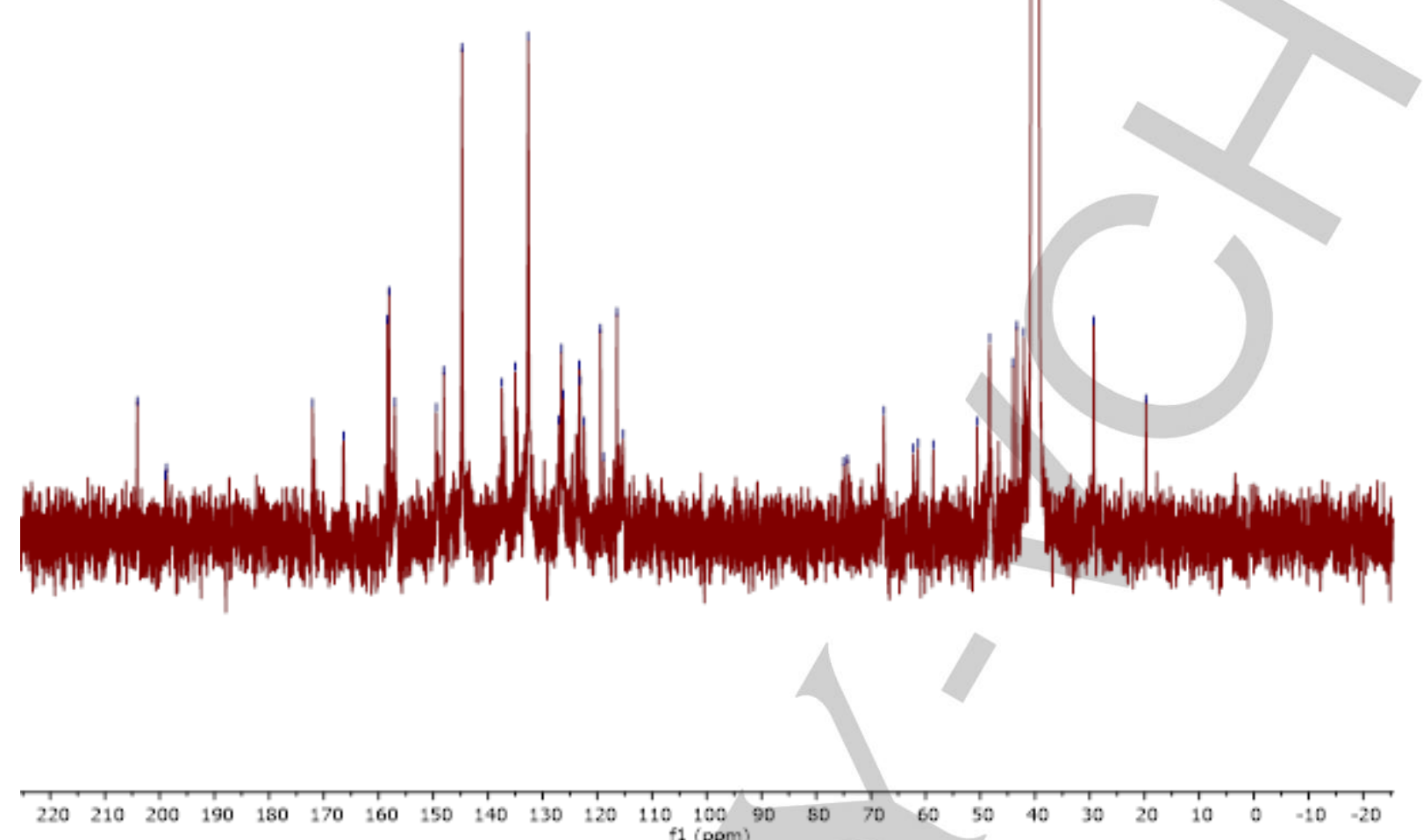

Figure $\mathbf{S 1 0} .{ }^{13} \mathrm{C}$ NMR of $\mathrm{L}_{3}\left(d_{6}\right.$-DMSO, $\left.100 \mathrm{MHz}, 298 \mathrm{~K}\right)$ 
P:IHULBOY_F7JHY_PA_C

National MS Facility LTQ Orbitrap XL
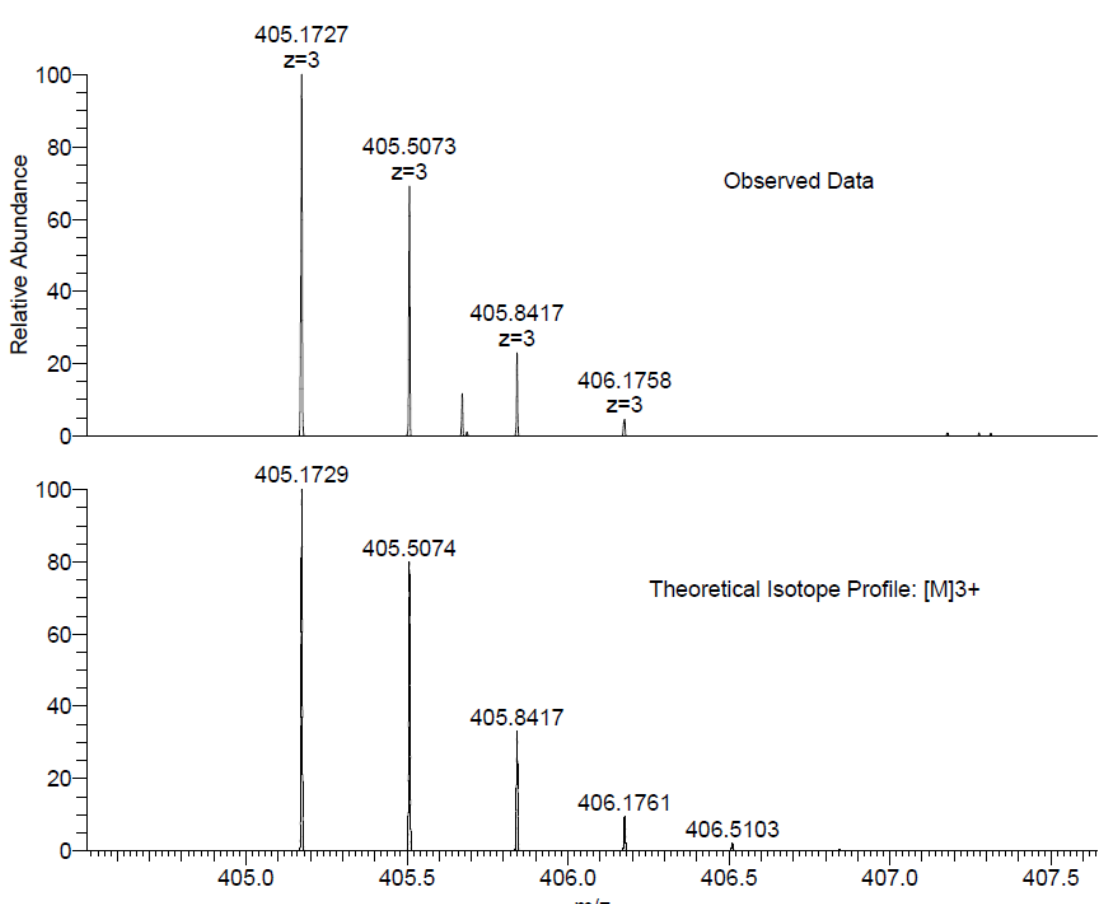

NL:

2.18E6

HULBOY_F7JHY_PA_C\#21

RT: 1.67 AV: 1 T: FTMS + p

ESI Full ms [150.00-1200.00]
NL:

1.02E4

$\mathrm{C}_{71} \mathrm{H}_{67} \mathrm{~N}_{12} \mathrm{O}$

$\mathrm{C}_{71} \mathrm{H}_{67} \mathrm{~N}_{12} \mathrm{O}_{8}$

p (gss, s

Theoretical Isotope Profile: [M]3+

405.8417

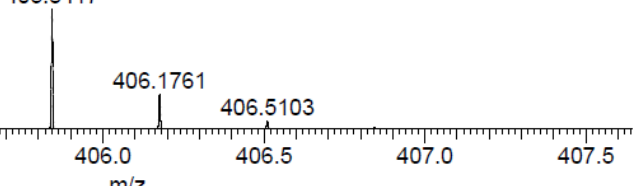

Figure S11. HRMS of $L_{3}$ 


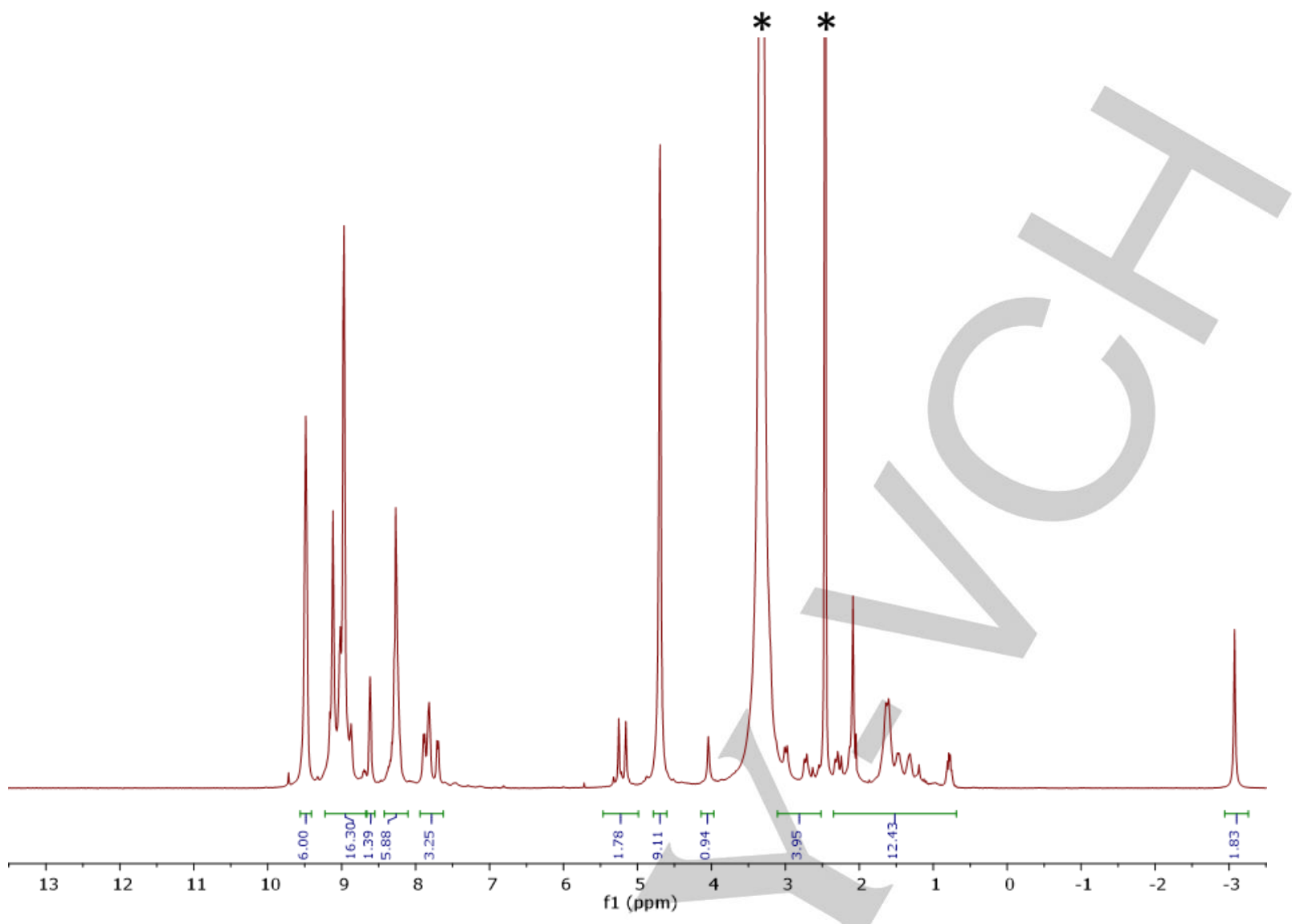

Figure S12. ${ }^{1} \mathrm{H} N M R$ of $\left[\mathrm{Ga}\left(\mathrm{L}_{3}\right)\right]\left(d_{6}\right.$-DMSO, $\left.400 \mathrm{MHz}, 298 \mathrm{~K}\right) .{ }^{*}$ indicates residual solvent signal. 
P:IHULBOY_F7MFF_PA_B YY224 MWt $=1386$ ?

$\mathrm{t}=1386$ ? $\mathrm{C} 71 \mathrm{H} 64 \mathrm{Cl} 3 \mathrm{GaN} 12 \mathrm{O}$

National MS Facility LTQ Orbitrap XL

27/06/2019 15:27:57
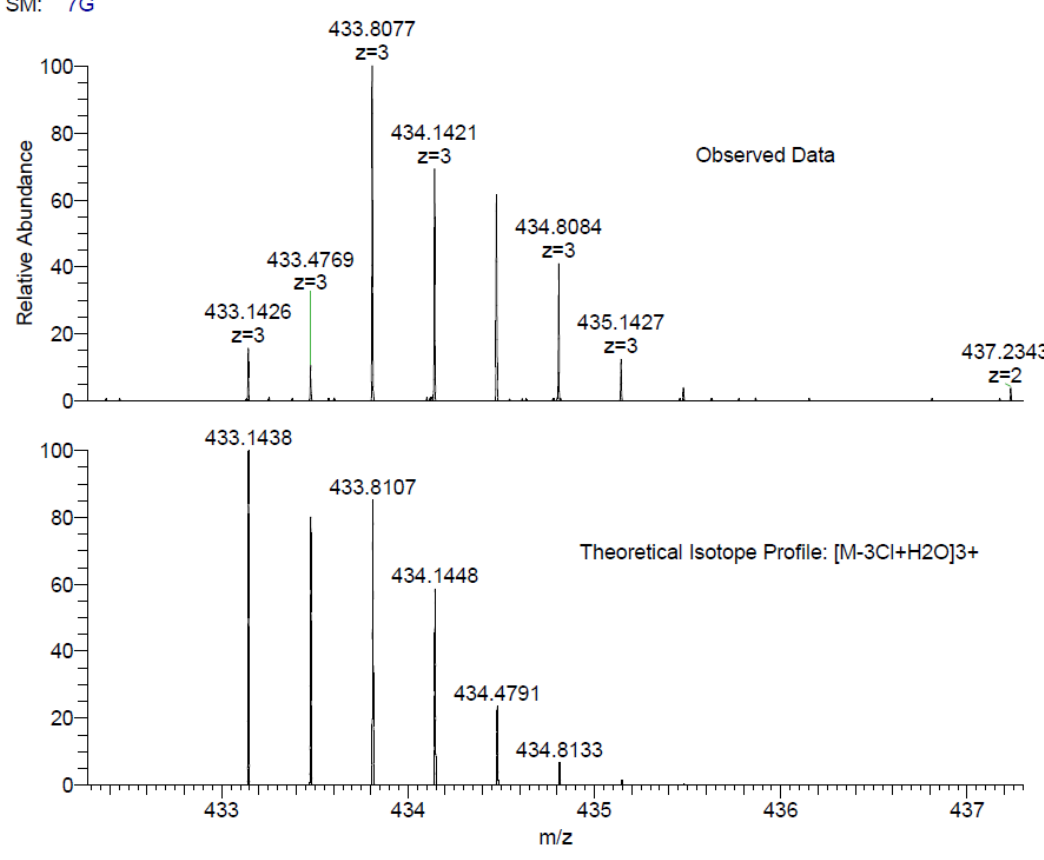


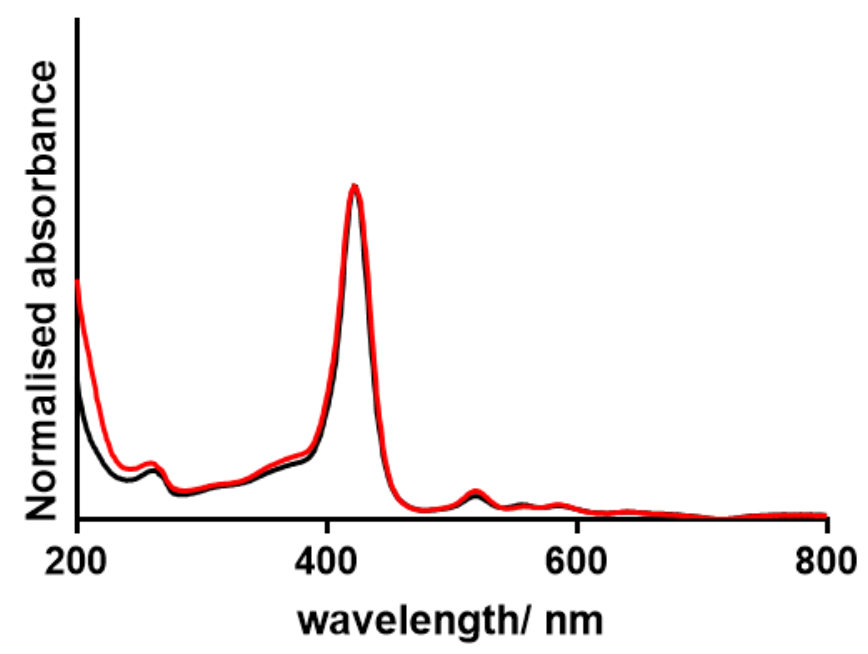

Figure S14. UV-Vis spectra of $\left[\mathrm{L}_{3}\right](\mathrm{Red})$ and $\left[\mathrm{Ga}\left(\mathrm{L}_{3}\right)\right]$ (Black) 


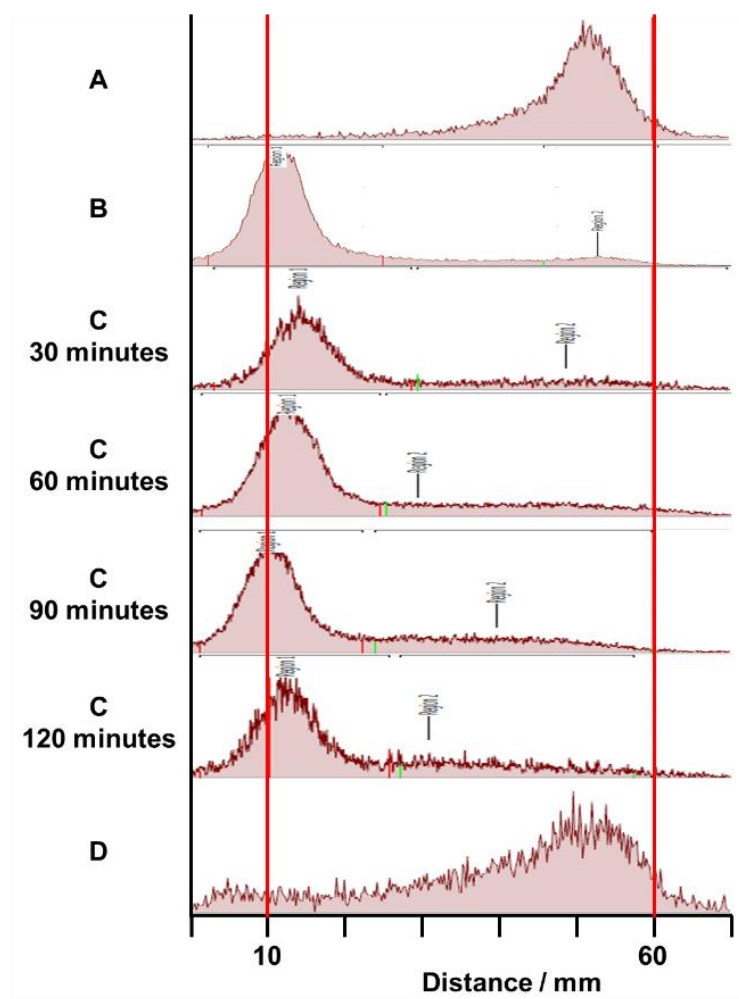

Figure S15. Radiolabelling of $\mathrm{L}_{3}$. A) $\left[{ }^{68} \mathrm{Ga}\right]\left[\mathrm{GaCl}_{3}\right]$ in aqueous solution. B) Radiolabelling mixture of $\mathrm{L}_{3}(100 \mu \mathrm{M})$ and $\left.\left[{ }^{68} \mathrm{Ga}\right][\mathrm{GaCl}]_{3}\right]$ following incubation at $95{ }^{\circ} \mathrm{C}$, for 15 minutes, $\mathrm{pH}$. C) Incubation of an aliquot of $\mathrm{B}$ with $\mathrm{FBS}$ at $37^{\circ} \mathrm{C}$ for indicated time period. D) $\left[^{68} \mathrm{Ga}_{[}\left[\mathrm{GaCl}_{3}\right]\right.$ incubated with $\mathrm{FBS}$. 


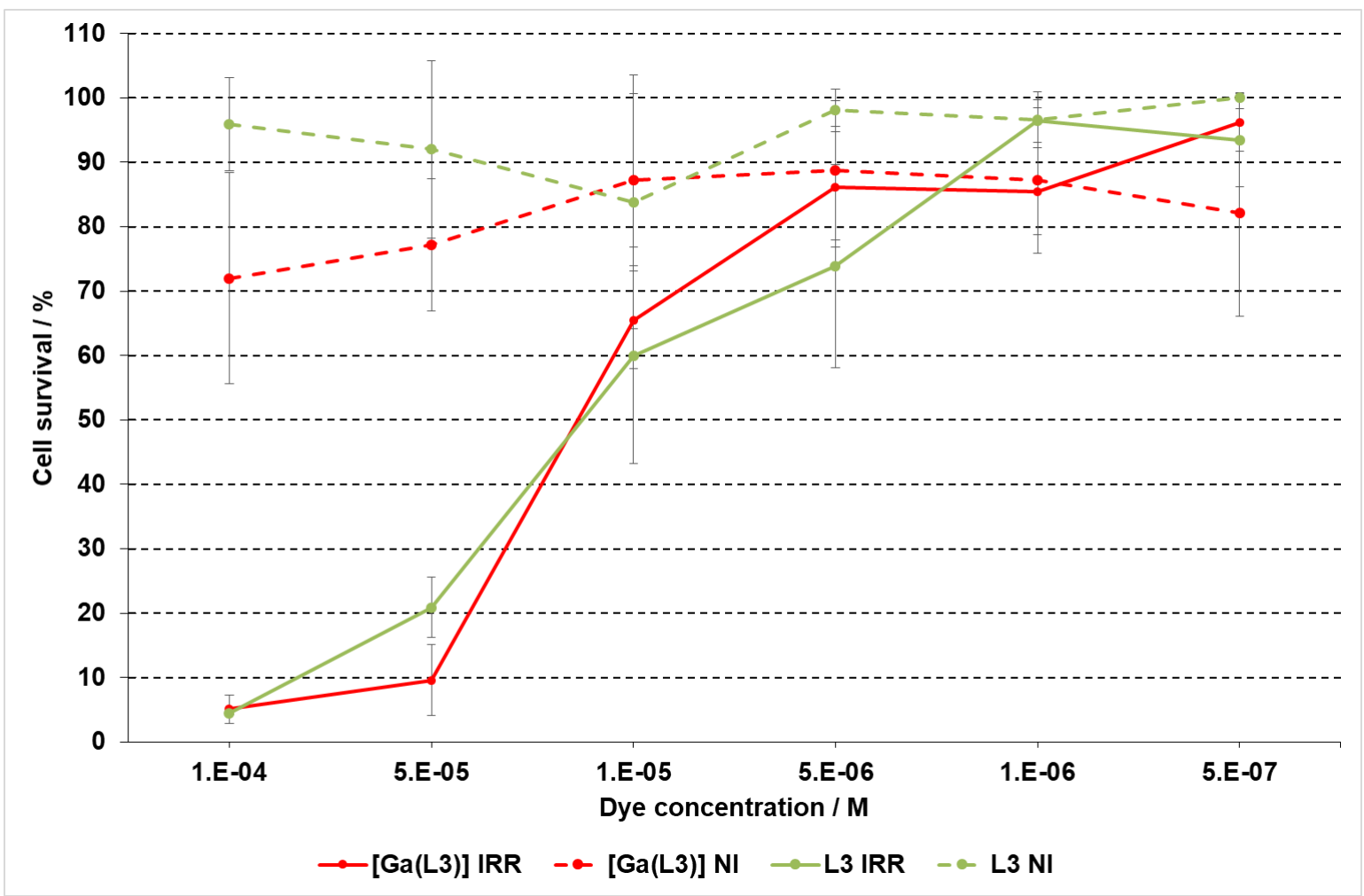

Figure S16. Toxicity of $L_{3}$ and $\left[G a\left(L_{3}\right)\right]$ in HT-29 cells. Solid Lines indicate irradiated measurements, dashed lines indicate non-irradiated cells 
Entry for the Table of Contents (Please choose one layout)

Layout 1:

\section{FULL PAPER}

In this study a bispidine ligand has been applied to the complexation of gallium(III) and radiolabelled with gallium-68 for the first time. The resulting complex is stable in serum for over two hours, showing a ligand system perfectly matched to the imaging window of PET. To show the versatility of ligand the bifunctional chelator was conjugated to porphyrin, producing a PET/PDT-theranostic,. This killed $>90 \%$ of HT-29 cells upon light irradiation at $100 \mu \mathrm{M}$.

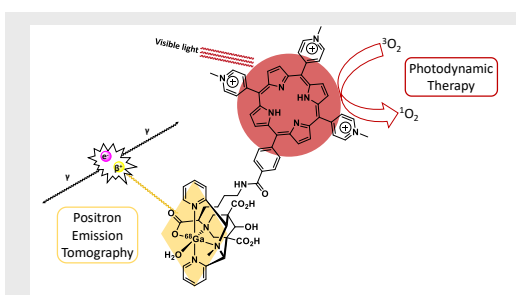

Dr Thomas W. Price, ${ }^{[\mathrm{a}, \mathrm{b}]} \operatorname{Dr}$ Steven $Y$. Yap,[] Dr Raphaël Gillet, ${ }^{[\mathrm{d}]}$ Huguette Savoie, ${ }^{[\mathrm{c}]}$ Prof. Loïc J. Charbonnière, ${ }^{[\mathrm{d}]}$ Prof. Ross W. Boyle, ${ }^{*[c]} \operatorname{Dr}$ Aline $M$. Nonat, ${ }^{*}[\mathrm{~d}] \mathrm{Dr}$ Graeme J. Stasiuk $k^{*[a, b]}$

Page No. - Page No.

Title Bispidine: a potential chelator for gallium-68

Layout 2:

\section{FULL PAPER}

((Insert TOC Graphic here; max. width: $11.5 \mathrm{~cm}$; max. height: $2.5 \mathrm{~cm})$ )
Author(s), Corresponding Author(s)*

Page No. - Page No.

Title 